\title{
SLOPES IN STIFF-FISSURED CLAYS AND SHALES
}

by

J. M. Duncan

P. Dunlop

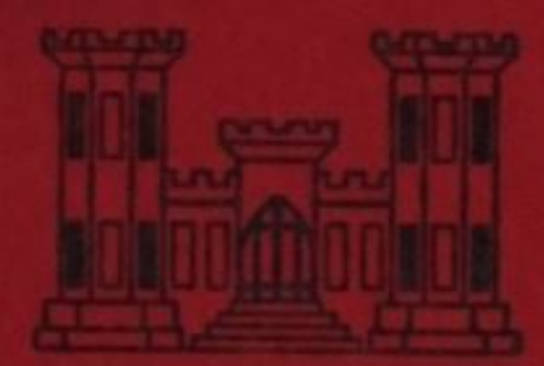

June 1968

Sponsored by

Office, Chief of Engineers

U. S. Army

Conducted for

U. S. Army Engineer Waterways Experiment Station CORPS OF ENGINEERS

Vicksburg, Mississippi

$$
\text { under }
$$

Contract No. DA-22-079-civeng-62-47

by

University of California

Berkeley California

THIS DOCUMENT HAS BEEN APPROVED FOR PUBLIC RELEASE AND SALE; ITS DISTRIBUTION IS UNLIMITED 
CONTRACT REPORT S-68-4

SLOPES IN STIFF-FISSURED CLAYS AND SHALES

A Report of an Investigation by

J. M. Duncan and Peter Dunlop

under

Contract No. DA-22-079-CIVENG-62-47

with

U. S. Army Engineer Waterways Experiment Station

Corps of Engineers

Vicksburg, Mississippi

June 1968

College of Engineering

Office of Research Services

University of California

Berkeley, California

Report No. TE 68-6 

The objective of this investigation was to review existing information concerning slope failures in stiff, fissured clays and shales, and to study the influence of lateral stresses on the stress conditions around excavated slopes. These studies, which were performed using the finite element method of analysis, show that the initial horizontal pressures have a considerable influence on the magnitudes of shear stresses following construction.

Shear stresses around excavated slopes are much larger for conditions representative of heavily overconsolidated clays (high initial horizontal stresses) than for conditions representative of normally consolidated clays (low initial horizontal stresses). Shear stresses large enough to cause failure at some points may develop even when the factor of safety calculated by the $\phi=0$ method of analysis is much larger than unity. The higher the horizontal stresses before excavation, the higher the factor of safety corresponding to the development of local failure. 
FOREWORD . . . . . . . . . . . . . . . . . . . . 3

SUMMARY . . . . . . . . . . . . . . . . . . . . 5

LIST OF SYMBOLS . . . . . . . . . . . . . . . . . . 9

LIST OF FIGURES . . . . . . . . . . . . . . . . . . . . . 11

LIST OF TABLES . . . . . . . . . . . . . . . . . . . . 13

INTRODUCTION . . . . . . . . . . . . . . . . . . . 14

REVIEW OF PREVIOUS WORK . . . . . . . . . . . . . . . 14

Analyses of Slope Failures . . . . . . . . . . . 14

Stress-Strain and Strength Characteristics . . . . . . . 17

Effects of Fissures . . . . . . . . . . . . 21

Effects of Initial Conditions . . . . . . . . . . . 22

STUDY OF THE EFHECTS OF INITIAL STRESSES . . . . . . . . . . 26

CONCLUSIONS • . • . . . . . . . . . . . . . . . . . 52

APPENDIX I - REFERENCES . . . . . . . . . . . . . . 54 
ENGLISH LETTERS

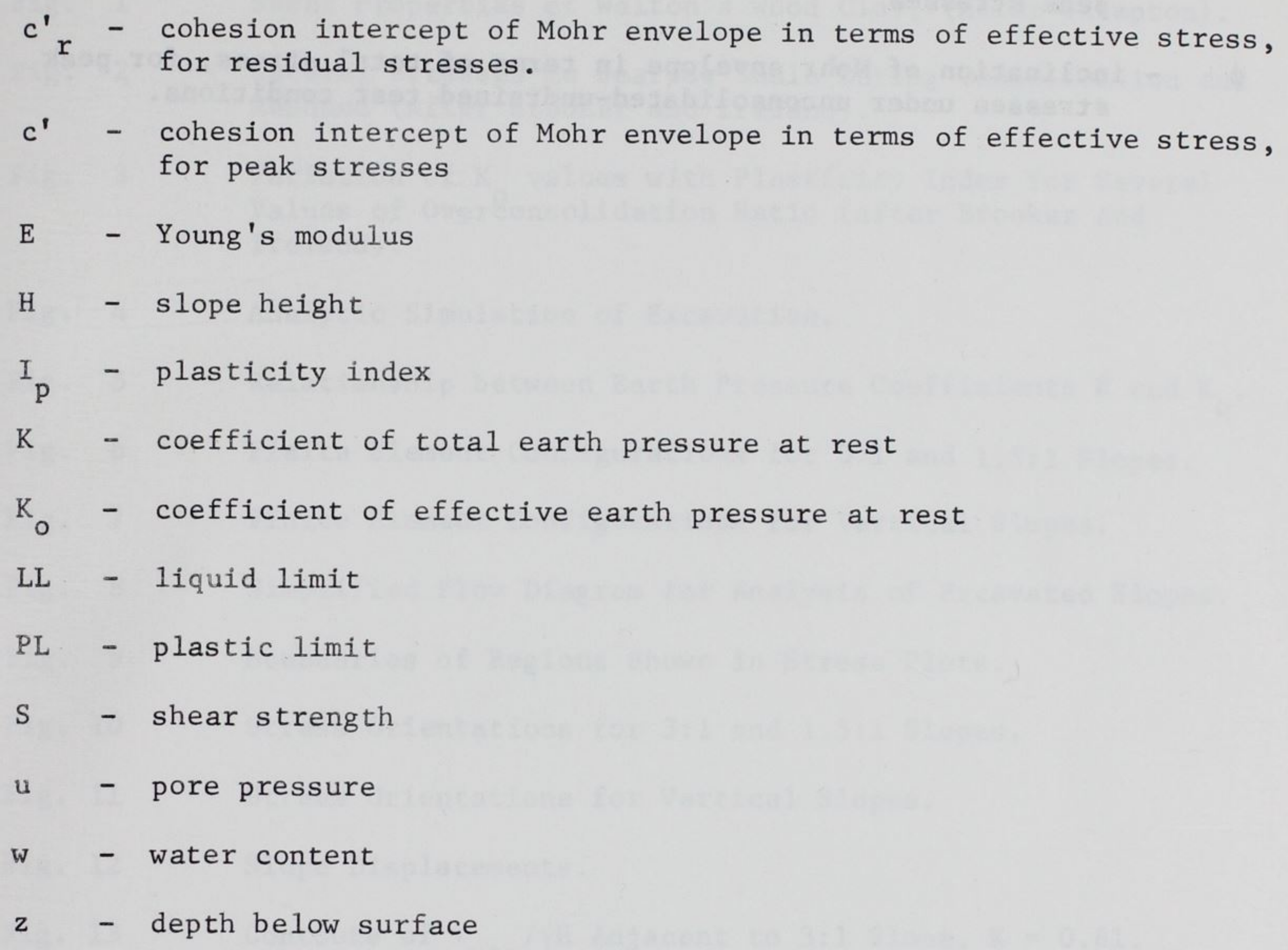

\section{GREEK LETTERS}

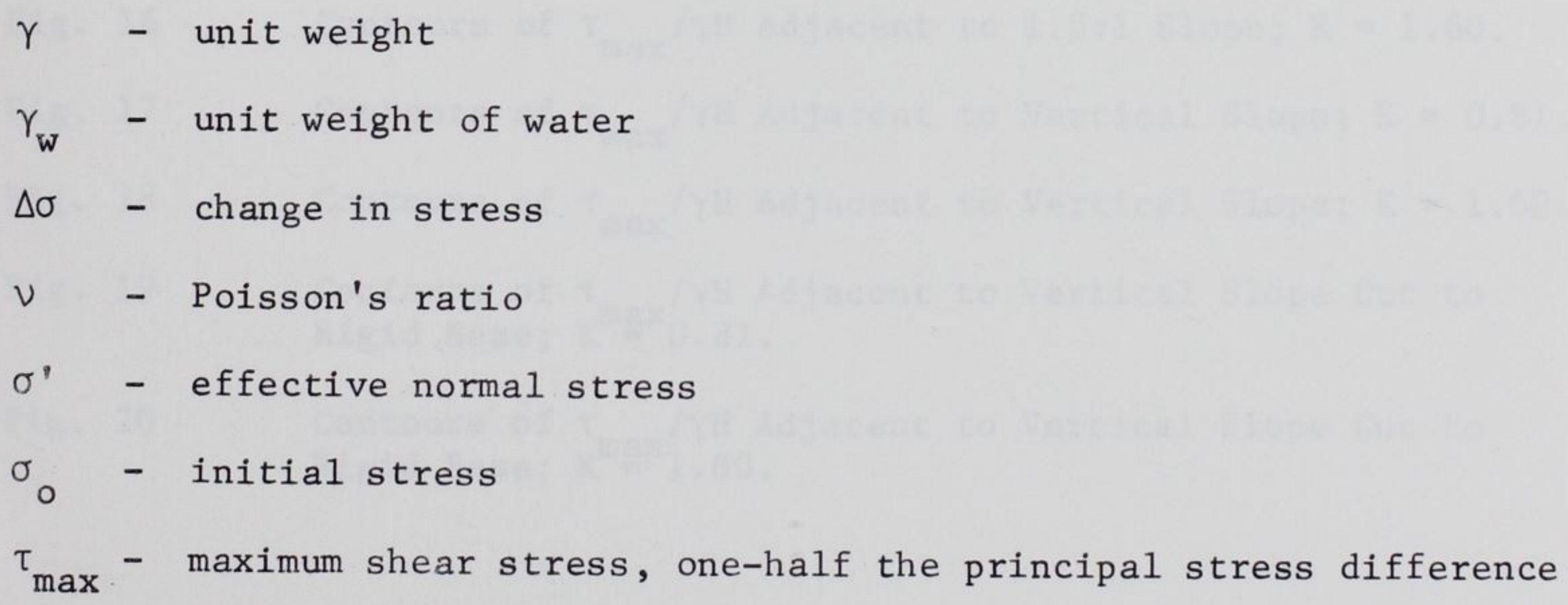


$\phi^{\prime} r$ - inclination of Mohr envelope in terms of effective stress, for residual stresses

$\phi^{\prime} \quad$ - inclination of Mohr envelope in terms of effective stress, for peak stresses

$\phi \quad$ - inclination of Mohr envelope in terms of total stress, for peak stresses under unconsolidated-undrained test conditions. 
Fig. 1 Shear Properties of Walton's Wood Clay, (after Skempton).

Fig. 2 Lateral Stresses in Bearpaw Shale During Consolidation and Rebound (after Brooker and Ireland).

Fig. 3 Variation of $\mathrm{K}_{\mathrm{o}}$ values with Plasticity Index for Several Values of Overconsolidation Ratio (after Brooker and Ireland).

Fig. 4 Analytic Simulation of Excavation.

Fig. 5 Relationship between Earth Pressure Coefficients $\mathrm{K}$ and $\mathrm{K}_{\mathrm{O}^{\circ}}$

Fig. 6 Finite Element Configurations for $3: 1$ and 1.5:1 Slopes.

Fig. 7 Finite Element Configurations for Vertical Slopes.

Fig. 8 Simplified Flow Diagram for Analysis of Excavated Slopes.

Fig. 9 Boundaries of Regions Shown in Stress Plots.

Fig. 10 Stress Orientations for $3: 1$ and 1.5:1 Slopes.

Fig. 11 Stress Orientations for Vertical Slopes.

Fig. 12 Slope Displacements.

Fig. 13 Contours of $\tau_{\max } / \gamma \mathrm{H}$ Adjacent to $3: 1$ slope, $\mathrm{K}=0.81$.

Fig. 14 Contours of $\tau_{\max } / \gamma \mathrm{H}$ Adjacent to $3: 1$ Slope; $K=1.60$.

Fig. 15 Contours of $\tau_{\max } / \gamma \mathrm{H}$ Adjacent to $1.5: 1$ Slope; $K=0.81$.

Fig. 16 Contours of $\tau_{\max } / \gamma \mathrm{H}$ Adjacent to $1.5: 1$ Slope; $K=1.60$.

Fig. 17 Contours of $\tau_{\max } / \gamma \mathrm{H}$ Adjacent to Vertical Slope; $\mathrm{K}=0.81$.

Fig. 18 Contours of $\tau_{\max } / \gamma \mathrm{H}$ Adjacent to Vertical Slope; $\mathrm{K}=1.60$.

Fig. 19 Contours of $\tau_{\max } / \gamma \mathrm{H}$ Adjacent to Vertical Slope Cut to Rigid Base; $\mathrm{K} \stackrel{\mathrm{max}}{=} 0.81$.

Fig. 20 Contours of $\tau_{\max } / \gamma \mathrm{H}$ Adjacent to Vertical Slope Cut to Rigid Base; $\mathrm{K}^{\mathrm{max}}=1.60$. 


\section{LIST OF TABLES}

Table 1 Slides in Stiff-Fissured Clays and Shales.

Table 2 Values of $\tau_{\max } / \gamma \mathrm{H}$ for Excavated Slopes.

Table 3 Values of $\mathrm{S}_{\mathrm{u}} / \gamma \mathrm{H}$ for Excavated Slopes. 


\section{INTRODUCTION}

The fact that heavily overconsolidated, fissured clays and clay shales present special slope stability problems was pointed out in 1936 by Terzaghi (39), who suggested grouping clays into three categories: soft, intact clays free from joints and fissures; stiff, intact clays free from joints and fissures; and stiff, fissured clays. The appropriateness of this grouping has since been demonstrated by a number of case histories, and a number of studies have been made in recent years to determine the causes of slope failures in stiff-fissured clays.

Several of these previous studies, which indicate that stifffissured clays and shales present more difficult slope stability problems than soft, intact clays, are reviewed in the following pages. These studies have shown that there are probably a number of reasons for these difficulties, including the stress-strain characteristics of heavily overconsolidated clays and shales, various effects of fissures, and the fact that the horizontal stresses in overconsolidated clays and shales may be quite large.

Following a review of previous work concerned with slides in stifffissured clays and shales and the physical properties of these materials, the effects of large horizontal stresses are considered in some detail. Stress analyses are described in which the excavation of slopes has been simulated analytically using the finite element method. These analyses were conducted to determine possible differences in the stress conditions around slopes excavated in heavily overconsolidated clays and in normally consolidated clay deposits.

\section{REVIEW OF PREVIOUS WORK}

Analyses of Slope Failures. A number of investigations of slope failures by Skempton $(32,33)$, Bishop and Bjerrum (5), Kenney (24) and others have shown that the stability of slopes in soft, intact clays may be assessed with reasonable accuracy using peak strength values from undrained laboratory tests for conditions immediately following 
construction, or from drained tests for long-term conditions, together with stability analyses based on equilibrium concepts. While stiff, intact clays are not encountered as frequently, analyses by Sevaldson (30) and by Skempton and Brown (35) have shown that slopes in these clays are amendable to the same methods of analysis.

Similar studies of slopes in stiff fissured clays and shales, however, have shown that the same methods of testing and analysis frequently lead to unsatisfactory results. Case histories showing that many slope failures in stiff-fissured clays and shales cannot be explained in terms of peak strength values and equilibrium methods of analys is have been presented by Henkel and Skempton (20), Henkel (21), Peterson, et al., $(28,29)$, Van Auken (40), Skempton (36), Skempton and LaRochelle (37), Hirschfeld, Whitman and Wolfskill (23), Beene (1) and Bjerrum (7), and a number of such cases have been summarized recently by Bjerrum (7). Table 1 contains data pertaining to a number of these failures. The clays in which these failures occurred are all heavily overconsolidated, having water contents close to the plastic limit, and all contain fissures. It may be noted that these case histories encompass a wide range in loading conditions, involving embankments, excavations and natural slopes. They also include a wide variation in the amount of time elapsed between changes in conditions and failure, varying from failure during or shortly following construction to failure after many years of stability.

The factors of safety shown in Table 1 have all been calculated using peak strength values or strength parameters corresponding to peak strengths, but they may not be directly comparable with one another, because they have been calculated using different methods of analysis. The short-term failures were analyzed using total stress methods, whereas the long-term failures were analyzed using effective stress methods, which Hansen (19) has shown involve different definitions of the factor of safety. Similarly, the effective stress analyses have been performed using various assumptions concerning side forces on slices, which Bishop (3) and Whitman and Bailey (43) have shown may result in different values for the factor of safety for the same conditions. Nevertheless, it is significant that the calculated factors of safety for the 
TABLE 1. SLIDES IN STIFF-FISSURED CLAYS AND SHALES

\begin{tabular}{|c|c|c|c|c|c|c|c|c|c|}
\hline \multirow{2}{*}{ SLIDE } & \multirow{2}{*}{$\begin{array}{l}\text { TYPE OF } \\
\text { SLOPE }\end{array}$} & \multirow{2}{*}{ HEIGHT } & \multirow{2}{*}{$\begin{array}{l}\text { TIME FROM END OF } \\
\text { CONSTRUCTION TO FAILURE }\end{array}$} & \multicolumn{3}{|c|}{ CLAY CHARACTERISTICS } & \multirow{2}{*}{$\begin{array}{l}\text { FACTOR OF } \\
\text { SAFETY }\end{array}$} & \multirow{2}{*}{$\begin{array}{l}\text { TYPE OF } \\
\text { ANALYSIS }\end{array}$} & \multirow{2}{*}{ REFERENCE } \\
\hline & & & & LI. & PL & w & & & \\
\hline North Ridge Dam, & Embankment & $70 \mathrm{ft}$. & Failed during construction & 72 & 21 & 36.5 & 1.23 & $\phi_{u}=0$ & Peterson, et. al., (1957) \\
\hline Seven Sisters, S-1 & Embankment & $17 \mathrm{ft}$. & Failed during construction & 85 & 26 & 45 & 1.8 & $\phi_{u}=0$ & Peterson, et. a1., (1960) \\
\hline Waco Dam & Embankment & $85 \mathrm{ft}$. & Failed during construction & 70 & 20 & 20 & - & - & VanAuken (1963); Beene (1967) \\
\hline Seven Sisters, S-6 & Embankment & $17 \mathrm{ft}$. & $\sim 5$ years & 85 & 26 & 45 & $\begin{array}{c}1.33 \text { to } \\
1.40^{\mathrm{a}}\end{array}$ & $\begin{array}{c}\text { Effective } \\
\text { Stress }\end{array}$ & Peterson, et. al., (1960) \\
\hline $\begin{array}{l}\text { South Saskatchewan } \\
\text { River Dam - Canal }\end{array}$ & Excavation & $\begin{array}{l}40 \text { to } \\
60 \mathrm{ft}\end{array}$ & Failed during construction & $80-150$ & $|18-27|$ & $19-35$ & $\sim 2.5^{b}$ & $\phi_{\mathrm{u}}=0$ & Peterson, et. al., (1960) \\
\hline Bradwell & Excavation & $48.5 \mathrm{ft}$. & 5 days & 95 & 30 & 33 & 1.8 & $\phi_{u}=0$ & Skempton \& LaRochelle (1965) \\
\hline Northolt & Excavation & $33 \mathrm{ft}$. & 19 years & 79 & 28 & 30 & 1.35 & $\begin{array}{c}\text { Effective } \\
\text { Stress }\end{array}$ & Henke1 (1957); Skempton (1964) \\
\hline Kensal Green & Excavation & $20 \mathrm{ft}$. & 29 years & 78 & 29 & 29 & 1.6 & $\begin{array}{c}\text { Effective } \\
\text { Stress }\end{array}$ & Henkel (1957); Skempton (1964) \\
\hline Sudbury Hill & Excavation & $23 \mathrm{ft}$. & 49 years & 82 & 28 & 31 & $\sim 2^{\mathrm{b}}$ & $\begin{array}{l}\text { Effective } \\
\text { Stress }\end{array}$ & Skempton (1964) \\
\hline Wood Green & Excavation & $37 \mathrm{ft}$. & 55 years & 78 & 30 & 31 & 1.32 & $\begin{array}{c}\text { Effective } \\
\text { Stress }\end{array}$ & Henke1 (1957) \\
\hline Jackfield & $\begin{array}{l}\text { Natural } \\
\text { Slope }\end{array}$ & $\sim 95 \mathrm{ft}$ & - & 44 & 22 & 21 & $\begin{array}{l}1.45 \text { to } \\
2.06\end{array}$ & $\begin{array}{l}\text { Effective } \\
\text { Stress }\end{array}$ & $\begin{array}{l}\text { Henkel \& Skempton (1955); } \\
\text { Skempton (1954) }\end{array}$ \\
\hline
\end{tabular}

${ }^{a}$ Factor of safety $=1.65$ by effective stress analysis including side forces on slices.

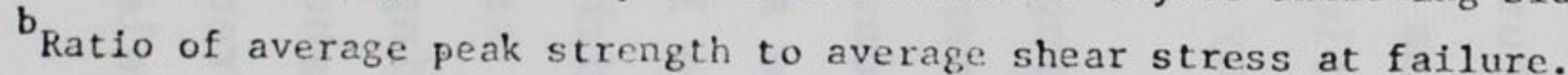


slopes are all greater than unity, whereas in fact the slopes all failed. Many investigators have concluded on the basis of this and similar evidence that the usual methods of strength testing and stability analysis are not suitable for slopes in stiff-fissured clays and clay shales.

Detailed analyses of slope failures and studies of the factors affecting the strength of stiff-fissured clays and clay shales by Peterson, et. al. (28,29), Skempton (36), Skempton and LaRochelle (37), Bjerrum (7), and Bishop (6) have shown that the stability problems associated with these clays stem from their stress-strain and strength behavior, the presence of fissures, and the initial stress conditions involving high values of horizontal stresses. The results of these investigations are summarized briefly in the following sections.

Stress-Strain and Strength Characteristics. Skempton (36) and Bjerrum (7) have shown that the stress-strain characteristics of heavily overconsolidated clays and shales, as well as their peak strengths, are important in determining the shear resistance which can be mobilized over extended periods of time. The drained stress-strain characteristics of one of the clays studied by Skempton, a heavily overconsolidated clay from Walton's Wood are shown in Fig. 1. Because the tests were conducted under direct shear test conditions, the magnitudes of the strains cannot be calculated; strain increases with increasing shear displacement, however, and a shear displacement of 2 inches or so would undoubtedly correspond to a very large value of shear strain. It may be noted that with continually increasing shear displacement, the shear resistance increases to a peak value and subsequently decreases to a residual value. Strength parameters determined by means of a number of such tests conducted at various values of effective normal stress are also shown in Fig. 1. The strength envelope corresponding to peak strength values is characterized by a sizable value of cohesion intercept, $c^{\prime}=320$ psf, whereas the envelope corresponding to the residual strength values has no cohesion intercept. In addition, the residual angle of shearing resistance, $\phi_{r}^{\prime}$ is less than the peak angle, $\phi^{\prime}$. Thus the values of shear strength and strength parameters are reduced at large values of shear deformation or strain. Tests conducted on specimens from a slip 

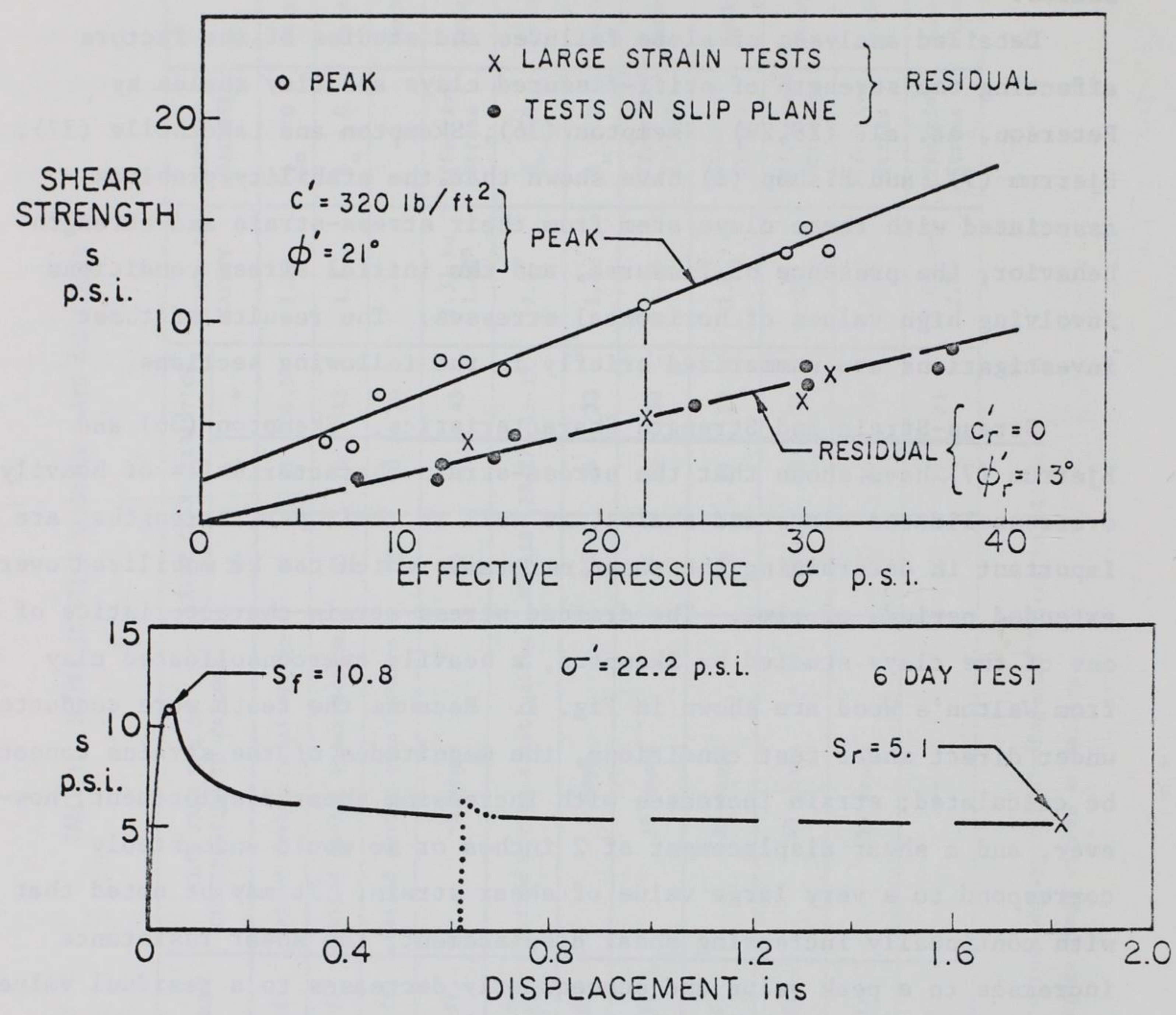

FIG. 1. SHEAR PROPERTIES OF WALTON'S WOOD CLAY, (after Skempton). 
plane within the Walton's Wood Clay, also shown in Fig. 1, indicate residual strengths commensurate with those determined in large-strain tests.

Similar behavior has been observed in tests on other stiff-fissured clays and shales; Herrman and Wolfskill (22) for example, have shown that the Cucaracha and Culebra clay shales from the Panama Canal Zone, and the Pierre shale from the Oahe damsite in South Dakota all exhibit greatly reduced shearing resistance when subjected to large shear deformations. Skempton (36) and Bjerrum (7) have shown, by detailed analyses of slope failures, that these stress-strain characteristics have an important influence on slope stability. On the basis of these analyses, Skempton suggested that slopes in stiff-fissured clays may fail by a progressive mechanism, the soil in various portions of the slip surface being successively strained beyond the peak (36).

Many of the best-documented cases believed to involve progressive failure have also involved a considerable period of time between construction and failure. In fact, Skempton (36) has shown that the time between construction and failure may increase as the average shear stress required for equilibrium decreases in relation to the peak strength. Table 1 contains data pertaining to three failures of excavated slopes in London clay which occurred 19 years, 29 years, and 49 years after construction; these three cases show that the longer the time between construction and failure, the smaller is the average shear stress in relation to the peak strength (36).

Although progressive failure may also be involved in short-term failures in stiff-fissured clays and shales, this has not been clearly established. The failure of an excavation in London clay at Bradwell, which occurred 5 days following the end of construction, has been explained by Skempton and LaRochelle (37) in terms of the effects of fissures and moisture migration on the average value of peak strength, with progressive failure playing at most a minor role. The average shear stress mobilized at failure of the Bradwell excavation slope was only about $55 \%$ of the peak undrained strength measured in short term laboratory tests. It is interesting to note that Bishop (6) found that the peak undrained strength of a similar clay determined by means of large- 
scale in-situ tests on 2-ft square specimens was also only about $55 \%$ of the value determined using smaller laboratory specimens. In both cases a major portion of the reduced field strengths as compared to the laboratory values was attributed to the influences of fissures. The peak strength of the clay involved in the Bradwell failure was also found to be smaller under sustained loading conditions than in rapid undrained tests, and Bishop indicated that the strengths in his large scale shear tests were influenced by anisotropy as well as the presence of fissures.

Tests conducted under conditions of sustained loading have shown that the undrained strengths of some overconsolidated clays and clay shales may decrease considerably with increasing test duration. Casagrande and Wilson (11) found that the undrained strength of Bearpaw shale measured in a test of one week duration was about $20 \%$ less than the strength measured in the usual rapidly conducted tests, and in tests of 30 days duration the strength was about $22 \%$ less. The strength loss for Cucaracha clay shale was even more dramatic, the average strength loss for several tests being about $60 \%$ after one week and $65 \%$ after one month. Skempton and LaRochelle (37) found that the strength of the brown London clay from the site of the Bradwell failure was about $20 \%$ less in tests of one week duration than in rapid undrained tests. About $3 / 4$ of this strength loss appeared to be attributable to moisture migration within the test specimens, the water content of the shear zones being distinctly higher than the remainder of the specimens after 7 days of sustained loading. The remainder of the strength reduction was attributed to a rheologic effect. Bishop (2), Ward, et. al. $(41,42)$, and Duncan and Seed (15) have shown that anisotropy may also play a significant role in determining the value of shear resistance which can be mobilized in heavily overconsolidated clays. Bishop found that the unconfined compressive strength of London clay from shallow depths varied considerably with specimen orientation; specimens trimmed so that their failure planes were horizontal were found to be about $28 \%$ weaker than specimens trimmed in the usual manner, with their axes vertical. Similarly, the undrained strength of an overconsolidated kaolinite clay was found to be about $25 \%$ less for failure on a horizontal plane than for specimens trimmed vertically (15). Ward, et. al. $(41,42)$ also found considerable variation in the undrained 
strength of London clay, depending on failure plane orientation. These results indicate that conventional laboratory tests on vertical specimens may significantly overestimate the undrained strength of heavily overconsolidated clays, particularly if the minimum strength value is associated with a horizontal failure plane orientation.

Effects of Fissures. Skempton and LaRochelle (37) have suggested that fissures may adversely influence the strength of heavily overconsolidated clays and shales in a number of ways: (1) Open fissures may form a portion of a failure surface across which there is no shear resistance; (2) closed fissures may form a portion of a failure surface on which only the residual strength can be mobilized; and (3) fissures, whether open or closed, may adversely influence the stresses within a slope, increasing the likelihood of progressive failure.

From their considerations of the possible explanations of the excavation slope failure at Bradwe11, Skempton and LaRochelle (37) concluded that undrained strength of the stiff-fissured London clay might be reduced as much as $30 \%$ by the presence of fissures. Similarly, Bishop (6) found that the peak undrained strength of London clay measured in large-scale direct shear tests was about $30 \%$ less than the peak strength of smaller laboratory specimens with the same failure plane orientation; Bishop attributed this difference in strength values to the fact that the larger specimens contain fissures and thus comprise a more representative sample. It may be noted in this connection that laboratory specimens containing obvious cracks or imperfections are sometimes rejected, a procedure which provides strength data primarily applicable to the intact clay.

Peterson, et. al. (29) found a considerable difference between the undrained strengths of large and small specimens of Bearpaw shale. Unconfined compression tests were conducted using specimens $1.4 \mathrm{in}$. diam. by $3.5 \mathrm{in.} \mathrm{high} \mathrm{and} 6.0 \mathrm{in.} \mathrm{diam.} \mathrm{by} 15.0 \mathrm{in}$. high. Specimens of both sizes were trimmed from samples obtained from two zones where the shale was classed as "medium" and "hard". The compressive strengths of smaller specimens from the medium zone averaged 53 psi, compared to only 20 psi for large specimens from the same zone; the average unconfined compression strength of small specimens from the hard zone was 300 psi, but the average unconfined compression strength for large specimens was only 50 psi. Thus 
the strength of larger, more representative specimens was less than the strength of smaller specimens from the same zone by $62 \%$ to $83 \%$. It is interesting to note that Peterson showed that the strength mobilized at failure of a canal bank at the South Saskatchewan River Dam project was also $60 \%$ less than the average undrained strength of small-size specimens, indicating that the failure might have been predicted using undrained strength values determined from laboratory tests on large specimens.

The considerable influence of specimen size on measured strength for London clay and Bearpaw shale indicates the desirability of studying the effects of specimen size when investigations are made of the undrained strength characteristics of other stiff-fissured clays and shales.

Continued study of the influence of specimen size could result in criteria relating joint spacing to the specimen size required to determine strength values appropriate for field conditions. Such criteria would be extremely useful for design studies.

In addition to their direct effects on shear strength, open fissures might increase the rate of swelling and strength reduction under conditions of reduced load. The length of drainage path for the interior portions of a slope in intact clay would be of the order of the slope height, whereas if the slope were transected by open fissures filled with free water, the length of drainage path would be reduced to a distance of the order of the spacing between fissures. Under these conditions considerable swell and strength loss might occur in a period of days or weeks, while a period of years would be required for the same degree of swelling in intact clays of similar permeability. Therefore, the strength of fissured clays in excavated slopes might under some conditions be reduced very quickly to a value less than the undrained strength, and it is possible that the use of the full undrained strength value would not be appropriate even for conditions immediately following construction.

Effects of Initial Conditions. Initial stress conditions in overconsolidated clays and shales, as well as their physical characteristics, may contribute to the slope stability problem they present. Field investigations $(26,27)$ have shown that the horizontal stresses in heavily overconsolidated clays may exceed the overburden pressure by $50 \%$ or even more in some cases. 
Failure of the supports in a tunnel through heavily overconsolidated clay were attributed by Langer (26) to the existence in the clay of horizontal stresses of the order of 3 times the overburden pressure. On the basis of similar types of observations Peterson (27) estimated that the horizontal stresses in Bearpaw shale were about 1.5 times as great as the overburden pressure at a point 65 feet beneath the ground surface.

A detailed study by Skempton (34) of the variation of horizontal stress with depth in London clay at Bradwell indicated that the ratio of horizontal to vertical effective stresses increased toward the surface, from a value of about 1.5 at a depth of $100 \mathrm{ft}$ to a value of 2.5 at $10 \mathrm{ft}$. Near the surface the horizontal pressure was approximately equal to the maximum passive pressure, indicating that in these shallow regions the horizontal stress had reached values sufficient to cause failure of the clay.

Kjellman (25), Bishop and Henkel (4) and Brooker and Ireland (8) have shown that under conditions of no lateral strain in laboratory tests, the ratio of lateral to axial effective stress (the coefficient of earth pressure at rest, $K_{0}$ ) increases with increasing degree of overconsolidation. The variations of lateral stress during axial loading and unloading of Bearpaw shale determined by Brooker and Ireland (8) are shown in Fig. 2. While the ratio of radial to axial stress is essentially constant during loading, its value increases during unloading to about 1.8. Brooker and Ireland also tested other soils, and from their results were able to determine the relationships between coefficient of earth pressure at rest, overconsolidation ratio, and plasticity index which are shown in Fig. 3. It may be noted that at an overconsolidation ratio of 32 , the largest shown, values of $\mathrm{K}_{\mathrm{o}}$ approaching 3 were determined for clays of low plasticity, while smaller values of $\mathrm{K}_{\mathrm{o}}$ were determined for more highly plastic clays at the same degree of overconsolidation.

Bjerrum (7) hypothesized that in highly plastic clays diagenetic bonds may form which inhibit the development of high lateral pressures during unloading, and result in considerable strain energy being stored in these clays after unloading. The stored strain energy could subsequently be released if the bonds were destroyed as a result of weathering. This hypothesis is consistent with the data in Fig. 3, which indicate that the 


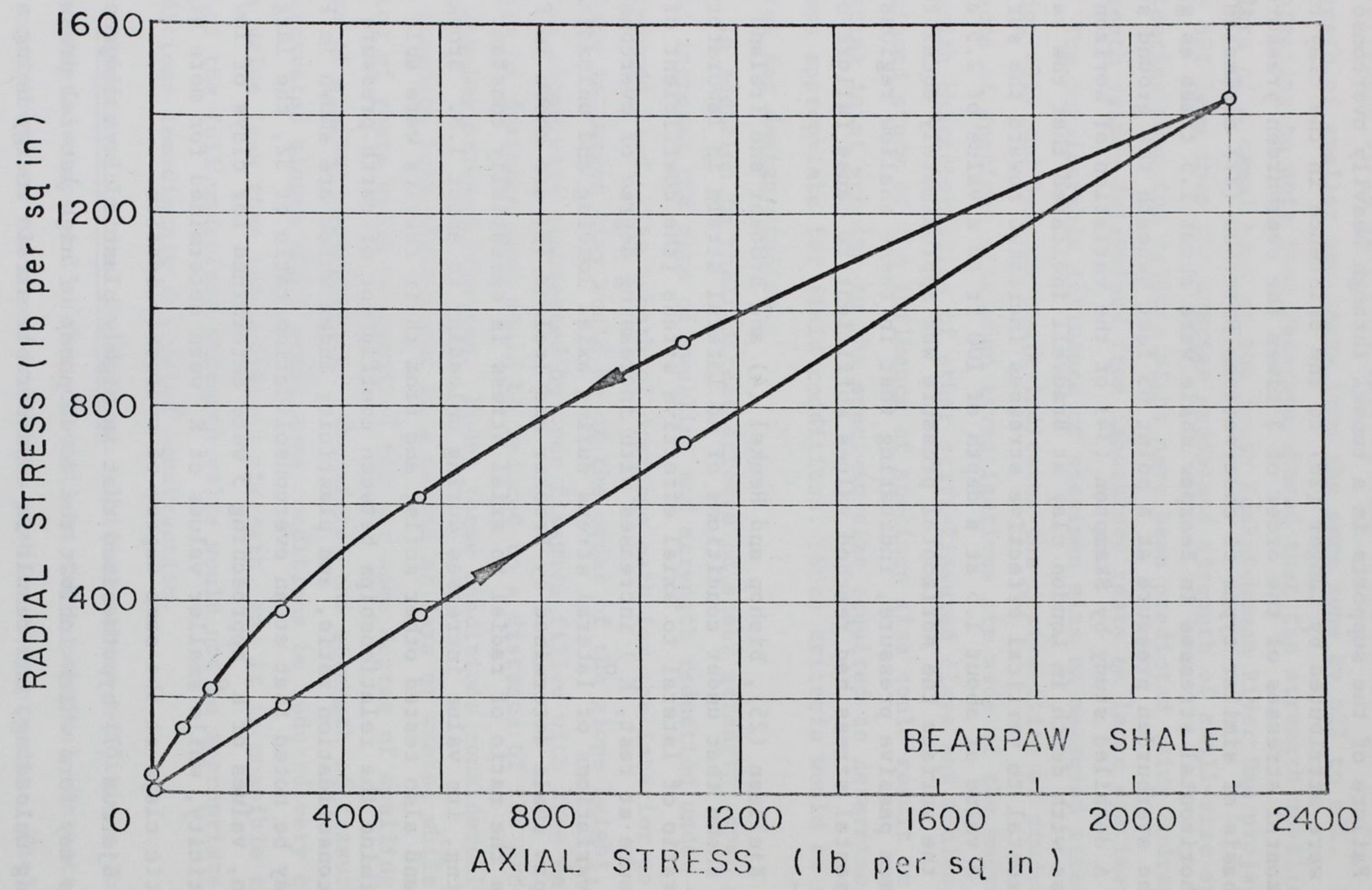

FIG. 2. LATERAL STRESSES IN BEARPAW SHALE DURING CONSOLIDATION AND REBOUND (after Brooker and Ireland). 


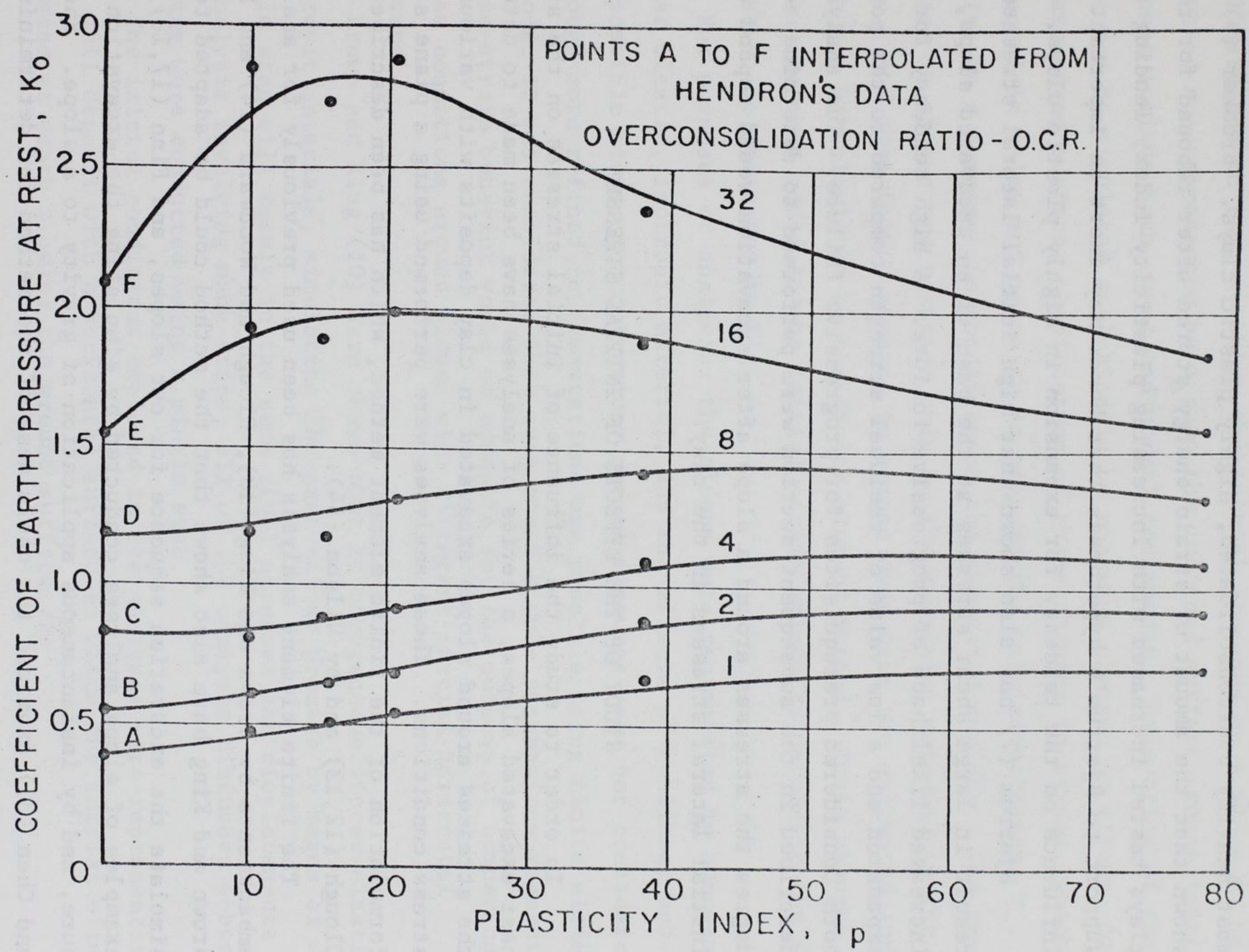

Fig. 3. VARIATION OF $K_{0}$ VALUES WITH PLASTICITY INDEX FOR SEVERAL VALUES OF OVERCONSOLIDATION RATIO (after Brooker and Ireland). 
value of $\mathrm{K}_{\mathrm{o}}$ decreases with increasing value of plasticity index for the most heavily overconsolidated, highly plastic clays. Brooker (9) has shown that the amount of strain energy stored after rebound for the clays tested increased with increasing plasticity index, lending further support to Bjerrum's hypothesis that bonds may exert an important influence on the tendency for expansion in highly plastic clays.

Bjerrum (7) has also shown that high initial lateral stresses could result in large shear stresses at the base of an excavated slope, and increased likelihood of progressive failure. A high tendency for lateral expansion and a low value of residual strength compared to the peak were both considered prerequisites for progressive failure. The analyses described in the subsequent section were performed to determine to what degree the stresses around a slope after excavation would depend on the initial lateral stresses in the clay.

\section{STUDY OF THE EFFECTS OF INITIAL STRESSES}

In order to study the influence of initial stresses on the stresses near excavated slopes, a series of analyses have been made to determine the stresses around slopes excavated in clay deposits with various initial stress conditions. These analyses were performed using a plane strain formulation of the finite element method, which has been described by Clough $(12,13)$ and by Wilson $(44)$.

The finite element analysis has been used previously for analyses of embankments by Brown and King (10), Clough and Woodward (14) and Finn (16). Brown and King have also shown that the method could be adapted to simulate the excavation sequence for cut slopes, and Finn $(17,18)$ showed examples of slope analyses conducted by simulating the excavation procedure, and by instantaneous application of gravity to a slope. Sherif and Chen (31) examined the usefulness of the method for determining pressures on yielding and nonyielding excavation bracing.

The present analyses were conducted to determine differences in behavior of slopes excavated in materials with low and high initial horizontal stresses, representative of normally consolidated and heavily overconsolidated clay deposits. The effects of various initial stress conditions were included in the analyses by simulating excavation of a 
slope in an initially horizontal deposit of clay. The analysis procedure is illustrated in Fig. 4, where the initial stresses on a slope to be excavated are represented by $\sigma_{0}$; on the inclined surface, these initial stresses include both shear and normal components. Excavation of the slope may be simulated analytically by applying changes in stress, $\Delta \sigma$, to the excavated surface. Application of these changes in stress, which are equal in value and opposite in sign to the initial stresses, $\sigma_{0}$, results in a stress-free condition on the excavated surface. The applied changes in stress are resisted only by the remaining material in the slope, and they induce changes in stress away from the excavated surface which may be calculated by the finite element method. These changes in stress are then added to the initial stress values to determine the final stresses, as indicated in Fig. 4.

For purposes of analysis, the slopes were represented by homogeneous, linear elastic, isotropic material, and the effects of nonlinear behavior and possible stress concentrations due to fissures were not considered. Although more refined representations are possible using finite element methods, it was considered that even these simple assumptions regarding stress-strain behavior would be adequate for the purpose of comparing stress conditions around slopes with different initial horizontal stresses.

Brown and King (10) have shown that in homogeneous linear elastic isotropic materials, simulating the excavations process by means of a single step will result in the same final stresses and displacements as an analysis involving many steps; all of the analyses discussed subsequently were conducted using a single step.

The initial conditions employed in the analyses were representative of a soil deposit with a horizontal surface in which the initial effective stresses at depth $z$ below the ground surface are

$$
\begin{aligned}
& \sigma_{\mathrm{v}}^{\prime}=\gamma z-u \\
& \sigma_{\mathrm{h}}^{\prime}=\mathrm{K}_{\mathrm{o}} \sigma_{\mathrm{v}}^{\prime}
\end{aligned}
$$

in which $\sigma_{\mathrm{v}}^{\prime}$ and $\sigma_{\mathrm{h}}^{\prime}$ are the vertical and horizontal effective stresses, $\gamma$ is the soil unit weight, $z$ is the depth below the surface, $u$ is the 


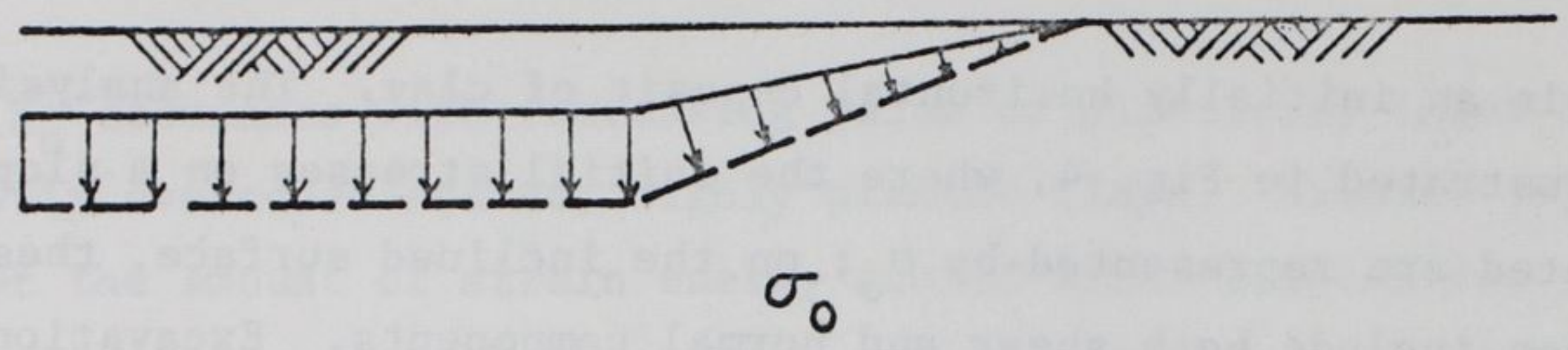

(a)

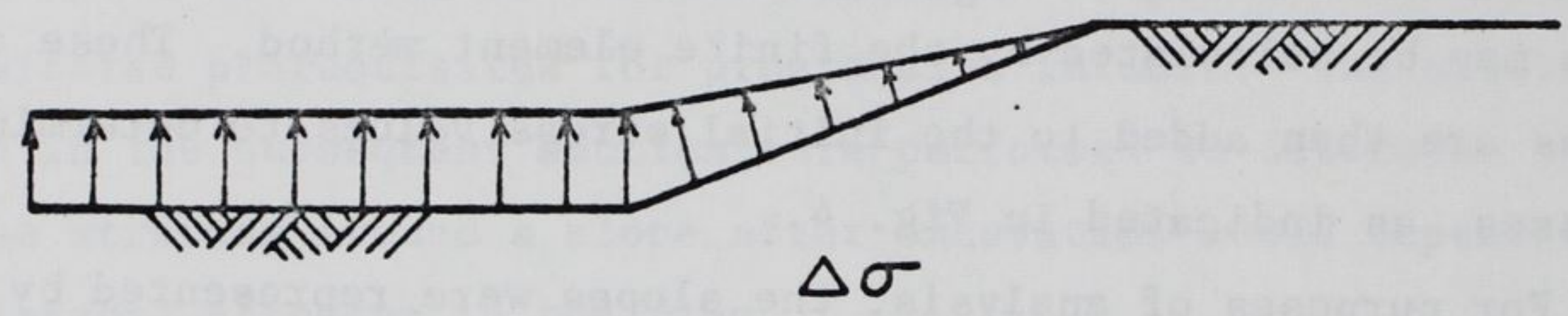

(b)

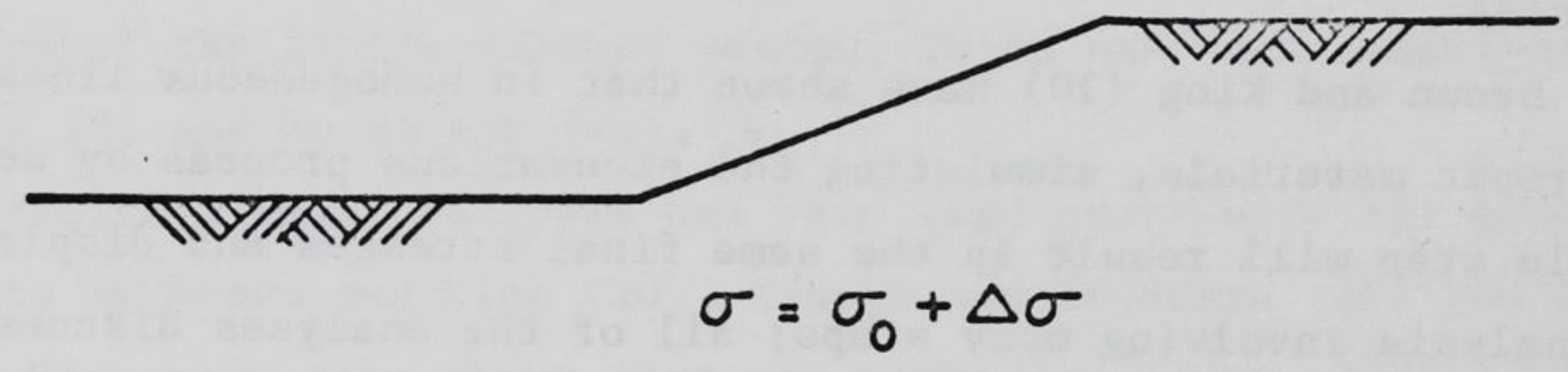

(c)

FIG. 4. ANALYTIC SIMULATION OF EXCAVATION. 
pore-water pressure, and $\mathrm{K}_{0}$ is the coefficient of earth pressure at rest. For a slope excavated in the dry, both the earth and water pressure are reduced to zero on the surface exposed by excavation. To simulate construction of such a slope it is convenient to describe the initial stress conditions in terms of a total stress pressure coefficient, $K$, such that

$$
\sigma_{\mathrm{h}}=\mathrm{K} \sigma_{\mathrm{v}}
$$

in which $\sigma_{h}$ and $\sigma_{v}$ are the horizontal and vertical total stresses. By definition, the coefficient $\mathrm{K}$ includes the effect of water as well as earth pressure. If hydrostatic conditions exist with the water table at the ground surface, and if the soil unit weight is constant, both the earth and water pressures will increase linearly with depth below the surface as indicated by equation 3 :

$$
\begin{aligned}
& \sigma_{\mathrm{v}}=\gamma \mathrm{z} \\
& \mathrm{u}=\gamma_{\mathrm{w}} \mathrm{z}
\end{aligned}
$$

in which $\gamma_{w}$ is the unit weight of water. Under these conditions the total stress earth pressure coefficient $K$ is related to the values of $K_{0}$ and $\gamma$ as indicated by equation 4 :

$$
\mathrm{K}=\mathrm{K}_{\mathrm{o}}+\frac{\gamma_{\mathrm{w}}}{\gamma}\left(1-\mathrm{K}_{\mathrm{O}}\right)
$$

It may be noted that the value of $\mathrm{K}$ is always closer to unity than the value of $\mathrm{K}_{\mathrm{o}}$. Variations of the value of $\mathrm{K}$ with the value of $\mathrm{K}_{\mathrm{o}}$ are shown in Fig. 5 for two values of soil unit weight, $\gamma$.

Slope analyses were conducted using two values of $\mathrm{K}$ considered to be representative of a normally consolidated clay $(\mathrm{K}=0.81)$ and a heavily overconsolidated clay $(K=1.60)$. For purposes of analysis the slopes were subdivided into a number of elements connected at their nodal points as shown in Figs. 6 and 7. Rectangular elements were used everywhere except along the sloping surfaces, where triangles and trapezoids were employed alternately. The quadrilateral elements were subdivided automatically by the computer program used into 4 triangles, and stress values associated with the quadrilateral elements are the average of the stresses in the four triangles, a technique which has been found to result in more accurate stress values than the use of triangular elements individually. The positions of the lateral boundaries shown in Figs. 6 and 7 


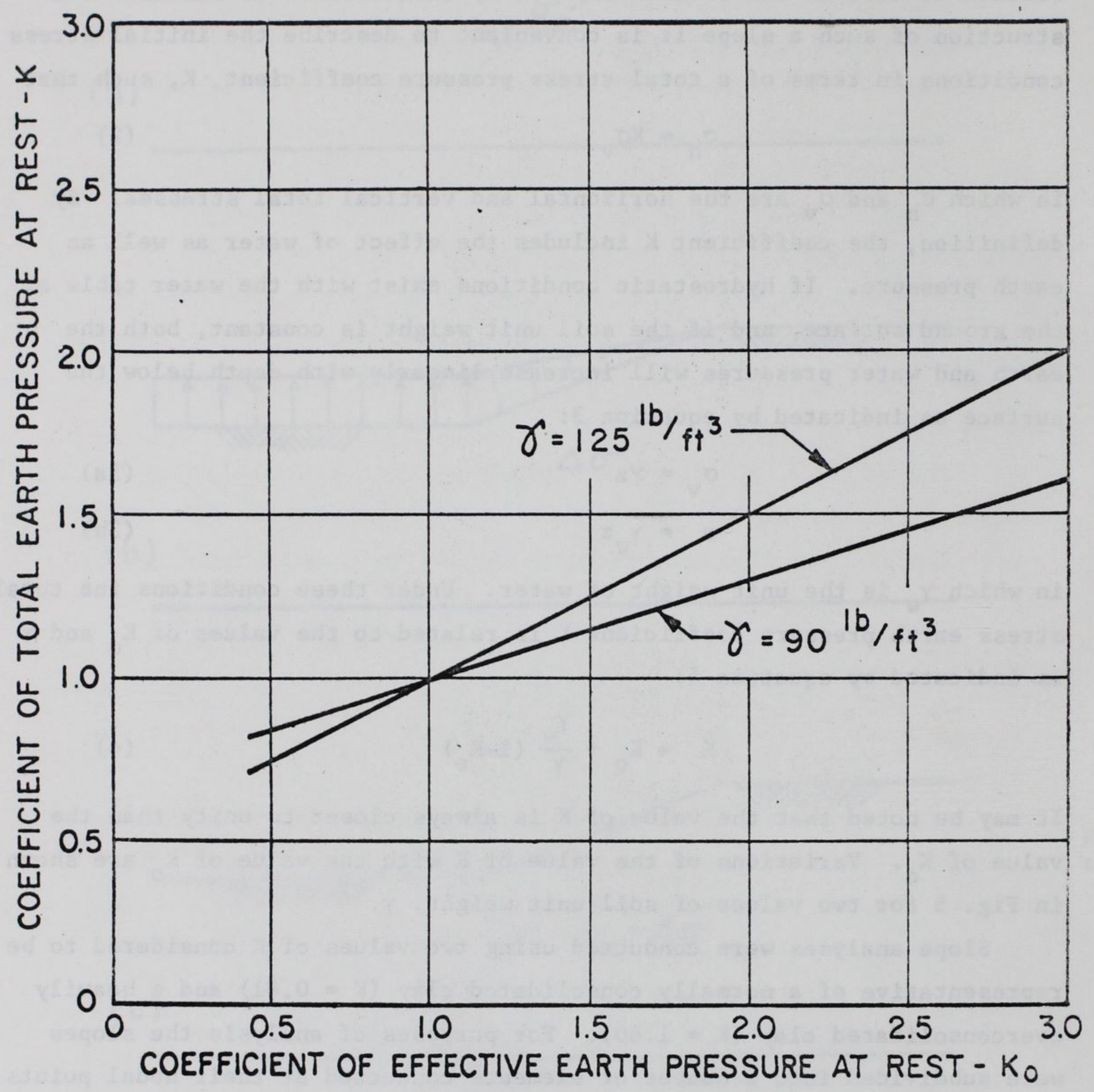

FIG. 5. RELATIONSHIP BETWEEN EARTH PRESSURE COEFFICIENTS $K$ AND $K_{0}$. 

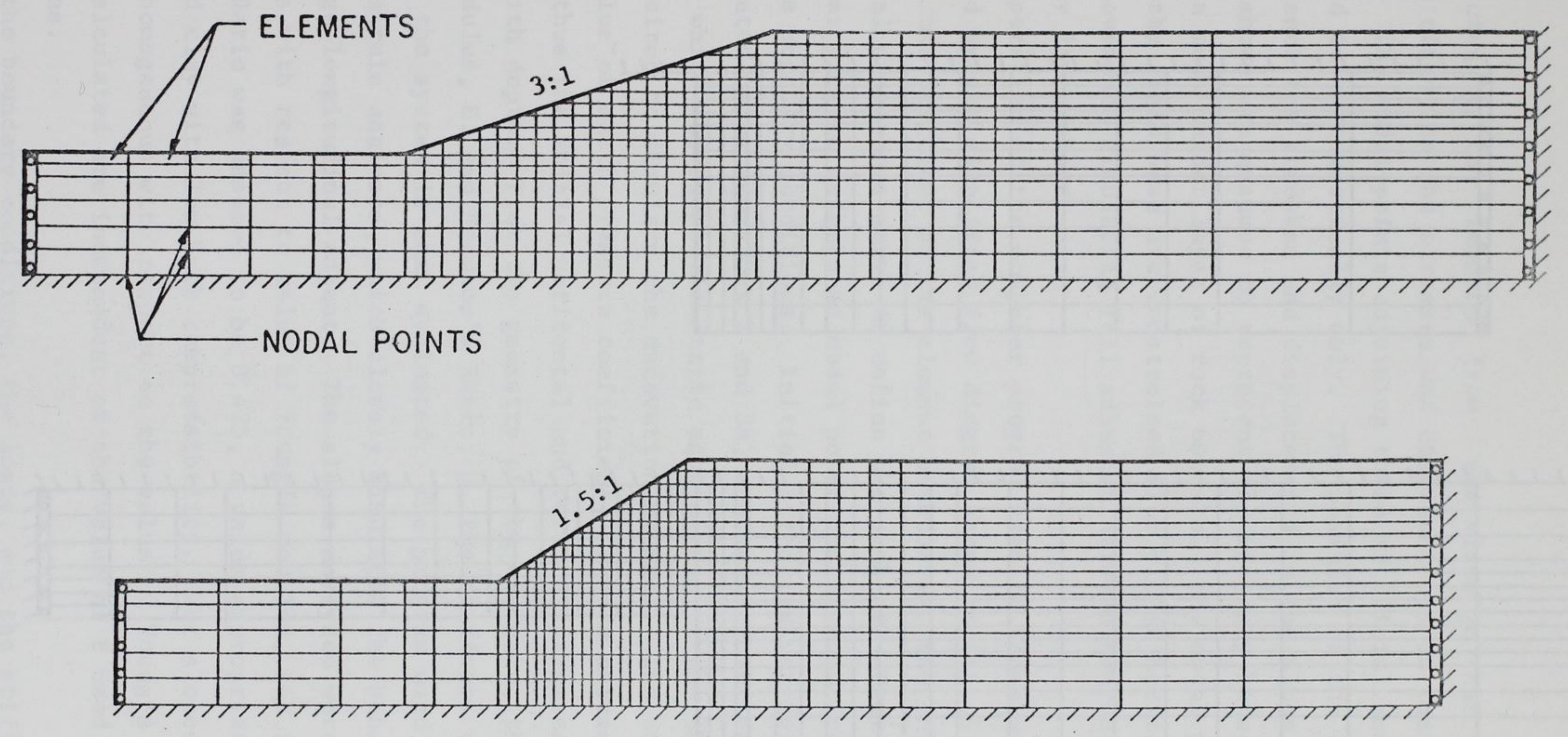

FIG. 6. FINITE ELEMENT CONFIGURATIONS FOR 3:1 AND 1.5:1 SLOPES. 

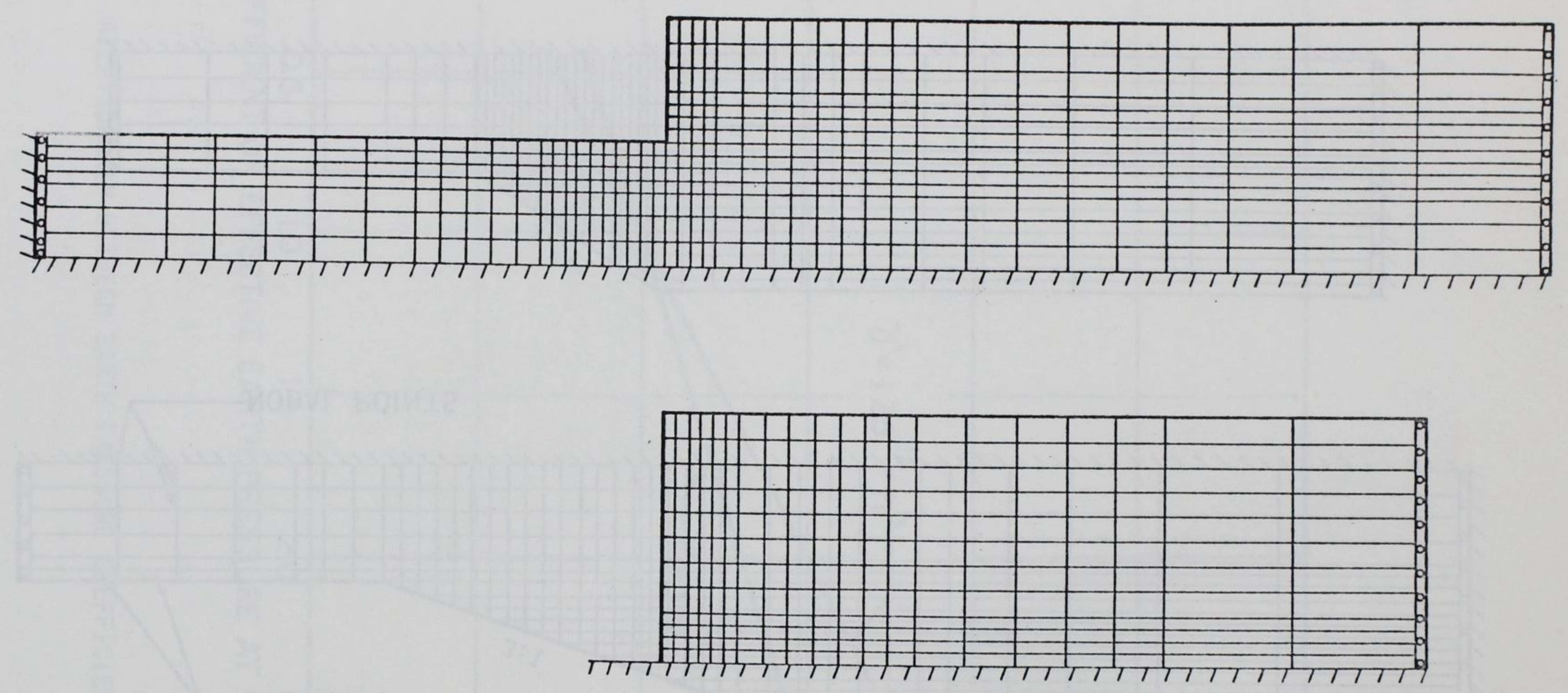

FIG. 7. FINITE ELEMENT CONFIGURATIONS FOR VERTICAL SLOPES. 
are sufficiently far removed from the slope so that they have a negligible effect on the stresses and displacements in the region of the slope. The nodal points adjoining these artificial boundaries are constrained to move vertically only. The position of the rigid base does influence the stresses and displacements in the slope region; the positions shown are assumed to represent the boundary between a clay layer and a much harder layer of rock beneath. The nodal points adjoining the rigid base are constrained from either horizontal or vertical movement, simulating full adhesion between bedrock and the softer clay layer above.

The operation of the computer program used in these analyses is illustrated by the simplified flow diagram shown in Fig. 8. Data describing the positions of the element boundaries, the initial stresses, and material properties serve to define the problem. From these data the computer program calculates nodal point coordinates and assigns appropriate boundary conditions. Initial stress values for each element are calculated using equations 2 and $3 a$, and nodal point forces are calculated which represent the static equivalents of the changes in stress required to simulate the excavation process. The unit weight, $\gamma$, and the value of earth pressure coefficient, $K$, were assumed to be constant; thus the initial horizontal and vertical stresses increased linearly with depth. From the geometry of the elements, their values of Young's modulus, E, and Poisson's Ratio, $\mu$, the stiffness of each element in the system is next evaluated. The program used is formulated for plane strain analyses, which closely simulates the behavior of slopes having large longitudinal extent. The slopes analyzed were assumed to be homogeneous with respect to value of Young's modulus, and the value of Poisson's Ratio was assumed to be 0.475 , a value appropriate to represent a saturated clay with low bulk compressibility. For slopes in materials which are homogeneous with respect to the value of Young's modulus, the stresses calculated are independent of the value of $\mathrm{E}$ used in the computations.

From the boundary conditions, the loads, and the stiffnesses of each nodal point, a system of equations ( 2 for each nodal point) is written, expressing the nodal point displacements in terms of the stiffnesses and 


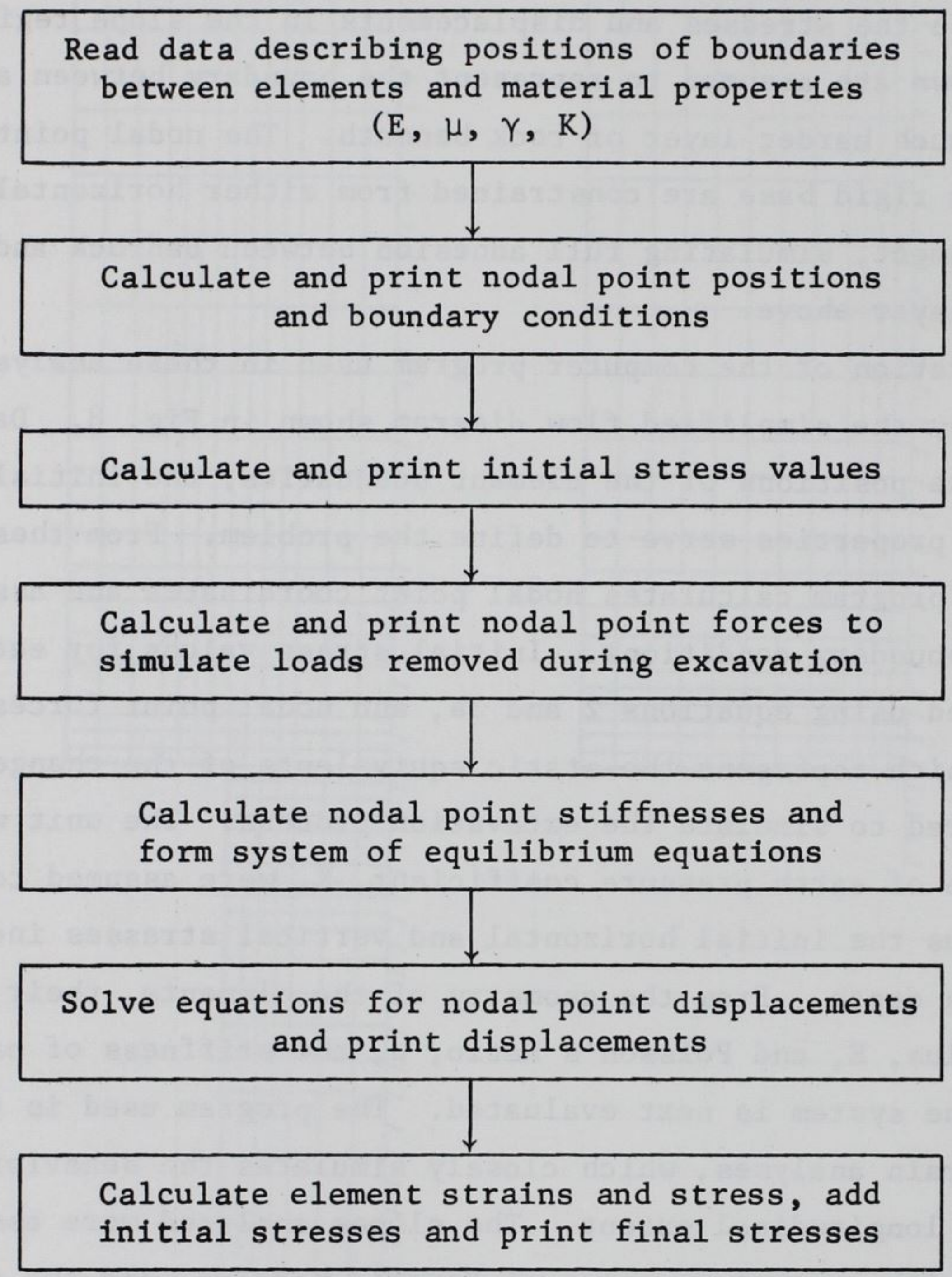

FIG. 8. SIMPLIFIED FLOW DIAGRAM FOR ANALYSIS OF EXCAVATED SLOPES. 
the applied loads. This system of equilibrium equations is then solved for the unknown nodal point displacements. Subsequently the strains and stresses within each element are evaluated, and the changes in stress are added to the initial stresses to determine the final state of stress in each element.

Although stresses were calculated for each element and displacements were calculated for each nodal point, only those in the immediate region of the slope are considered in the ensuing discussion. The boundaries of the regions considered are shown in Fig. 9; within these regions the stresses are influenced to a negligible extent by the lateral boundaries, and the results are thus representative of slopes in a clay layer of very large lateral extent.

The post-excavation stress orientations are shown in Figs. 10 and 11; the major principal stress direction indicated by the longer of the two lines forming each cross; the lengths of the lines do not indicate the stress magnitudes. The final stress orientations are dependent to a large degree on the value of the earth pressure coefficient, $K$. A value of $\mathrm{K}$ less than unity represents an initially vertical orientation of the major principal stress, and $\mathrm{K}$ greater than unity represents an initially horizontal orientation. The final stress orientations are similarly more nearly vertical for $K=0.81$ than for $K=1.60$. In each case shown, the major principal stresses are oriented approximately vertically near the surface behind the crest of the slope regardless of the value of $K$. In the cases in which the slopes have not been cut to the rigid base, the major principal stresses are oriented approximately horizontally near the bottom of the cut in front of the toe of the slope. Comparing the orientations for the two vertical slope configurations analyzed, it may be noted that the major principal stress direction is more nearly horizontal near the elevation of the toe of the slope for those cases in which the slope is cut completely to the rigid base, indicating larger shear stresses on the horizontal plane as a result of increased rigidity at this level.

The deformed shapes of the slopes after excavation are shown in Fig. 12. Each of the diagrams in Fig. 12 is plotted to the same dimensionless scale in which the unit of measure shown in the figure is $\gamma \mathrm{H}^{2} / \mathrm{E}$, 


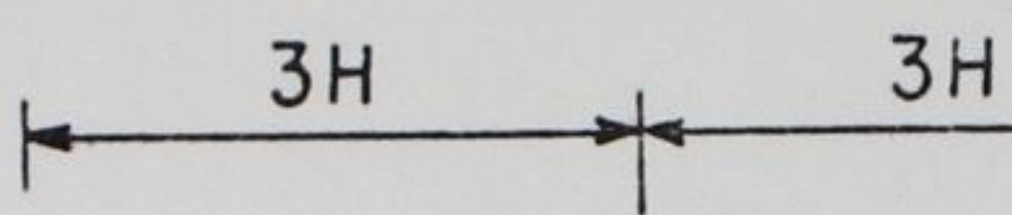

$6 \mathrm{H}$
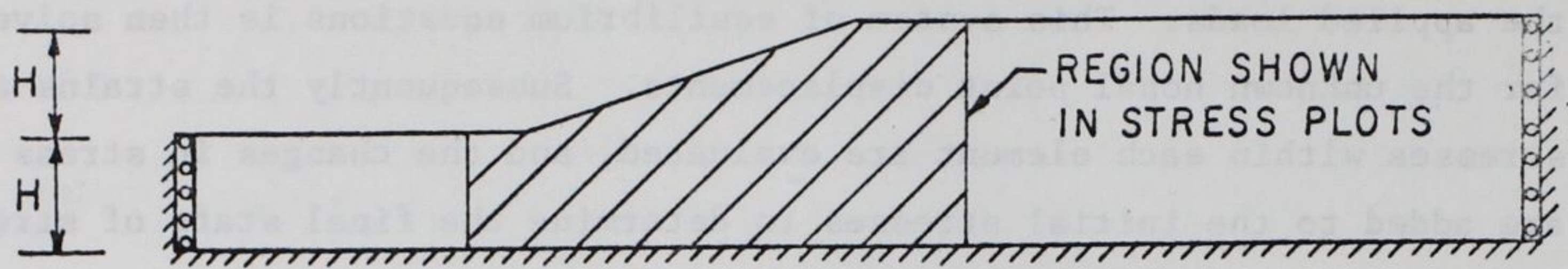

3:1 SLOPE
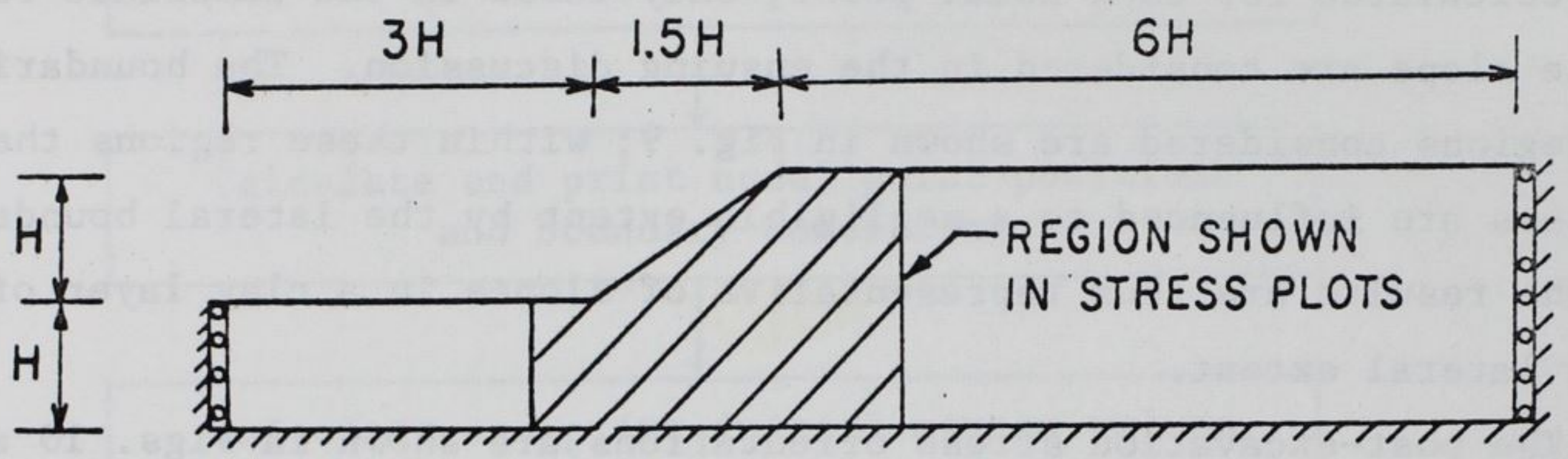

1.5:। SLOPE

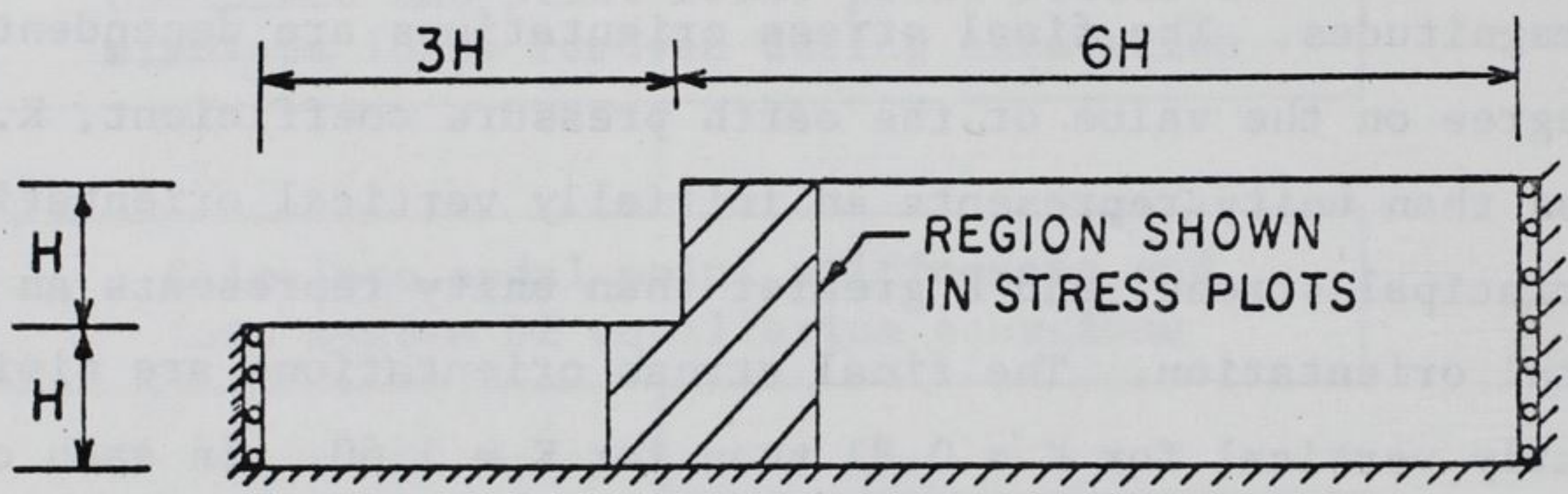

VERTICAL SLOPE

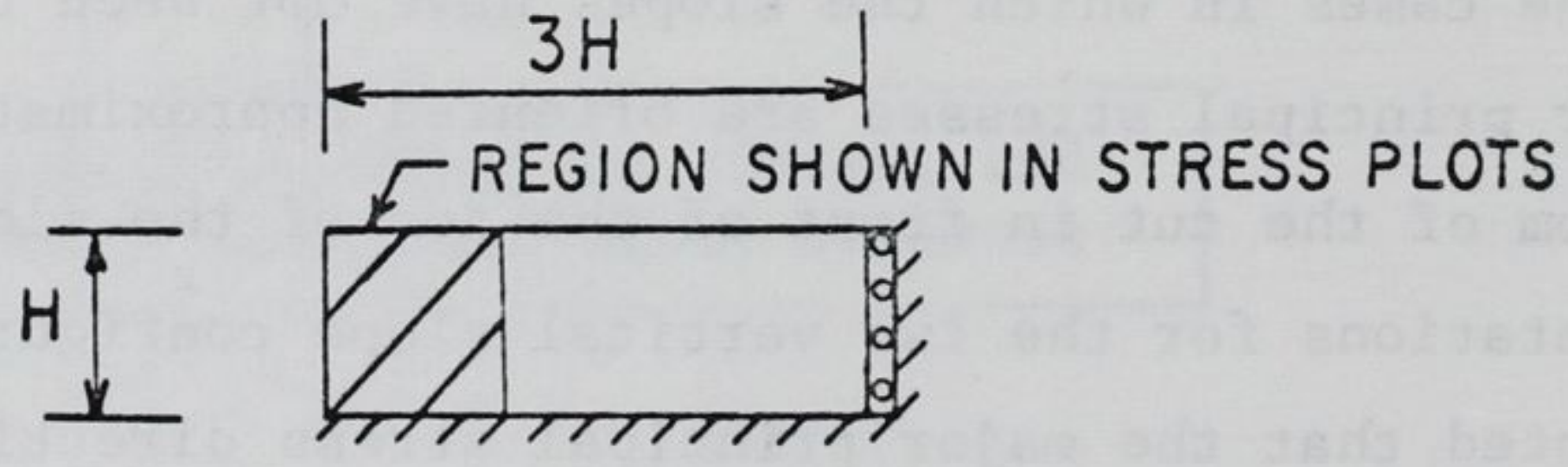

VERTICAL SLOPE CUT TO RIGID BASE

FIG. 9. BOUNDARIES OF REGIONS SHOWN IN STRESS PLOTS. 

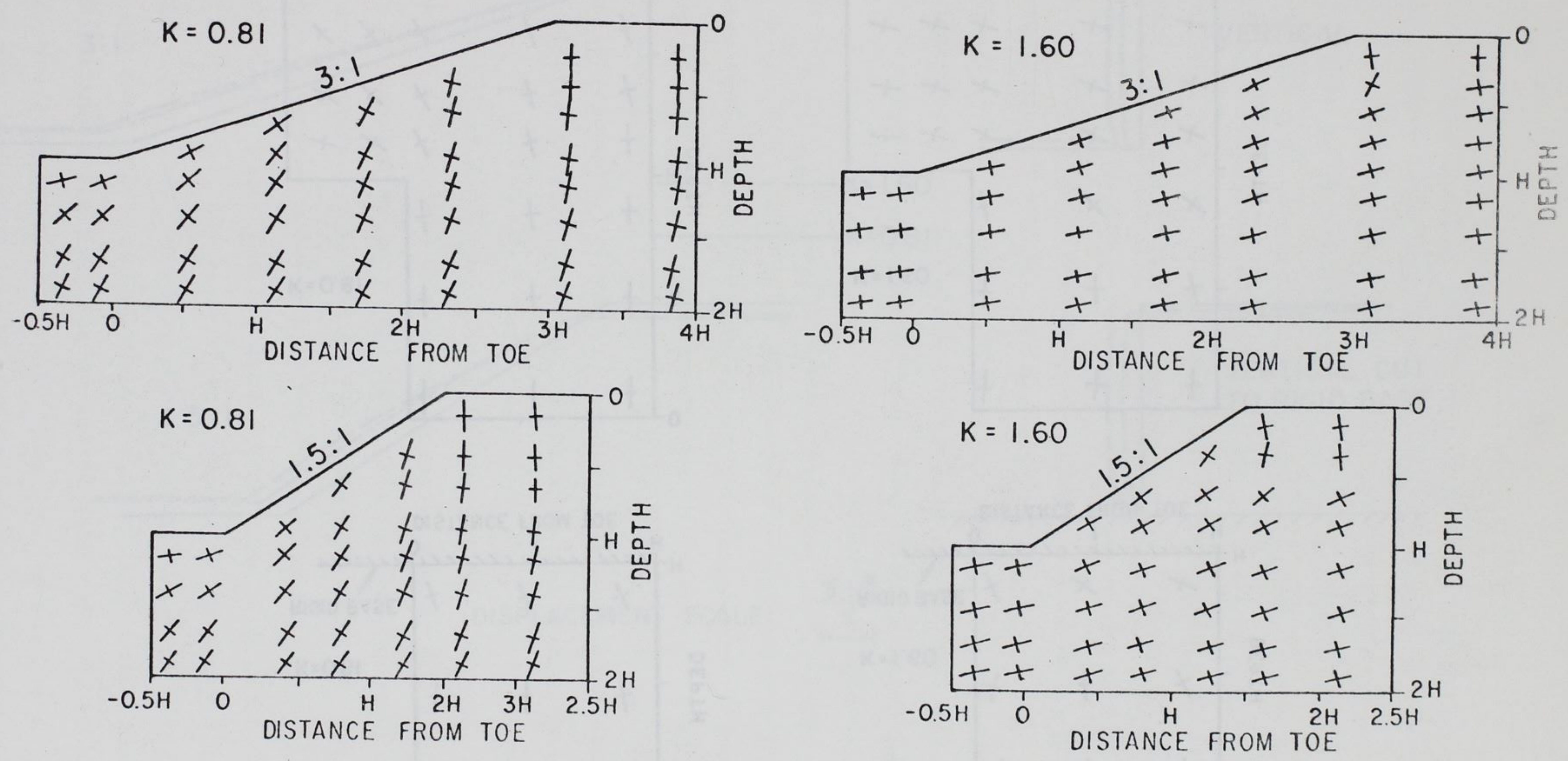

FIG. 10. STRESS ORIENTATIONS FOR 3:1 AND 1.5:1 SLOPES. 


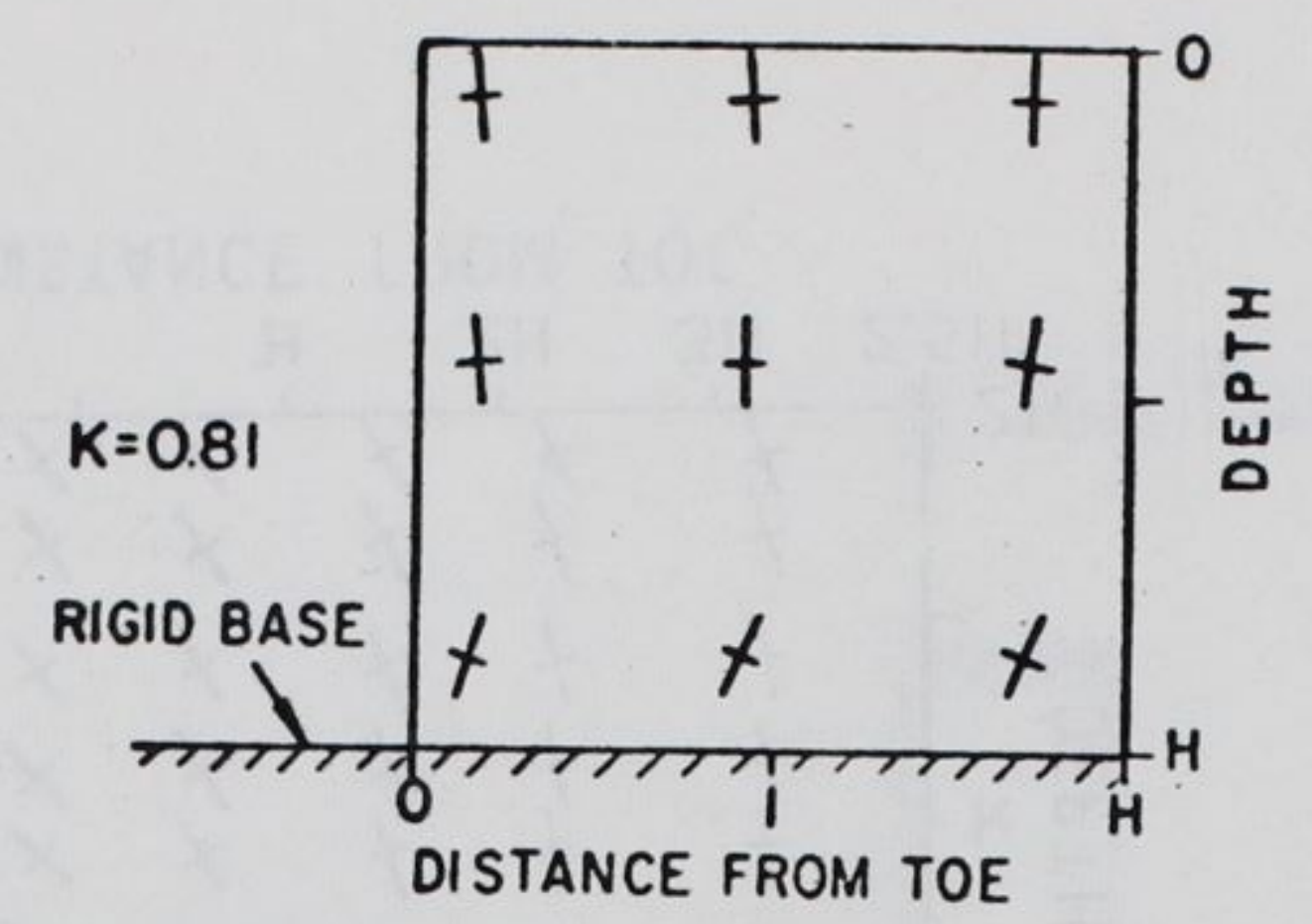

$\stackrel{\omega}{\infty}^{\omega}$
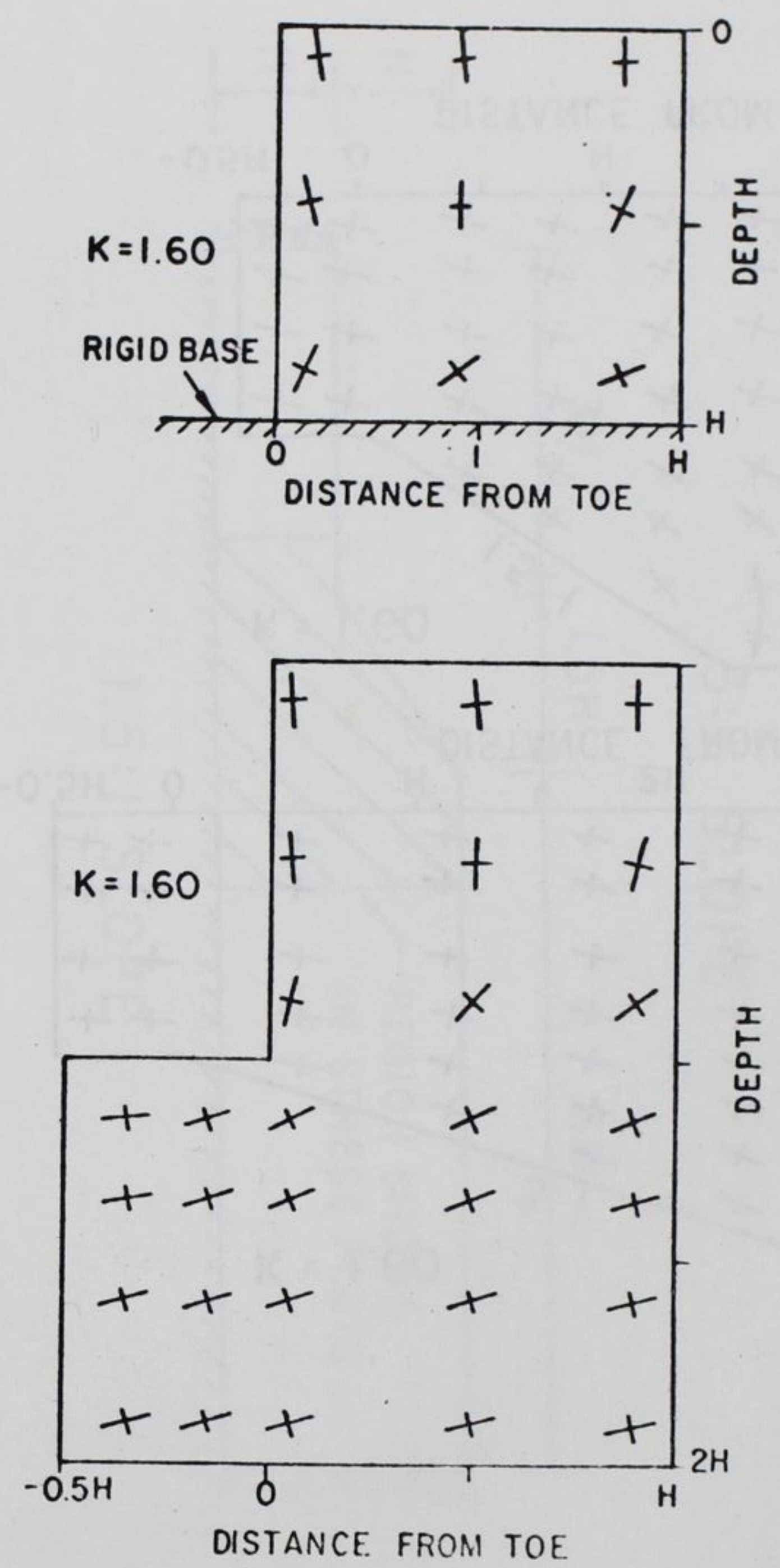

FIG. 11. STRESS ORIENTATIONS FOR VERTICAL SLOPES. 

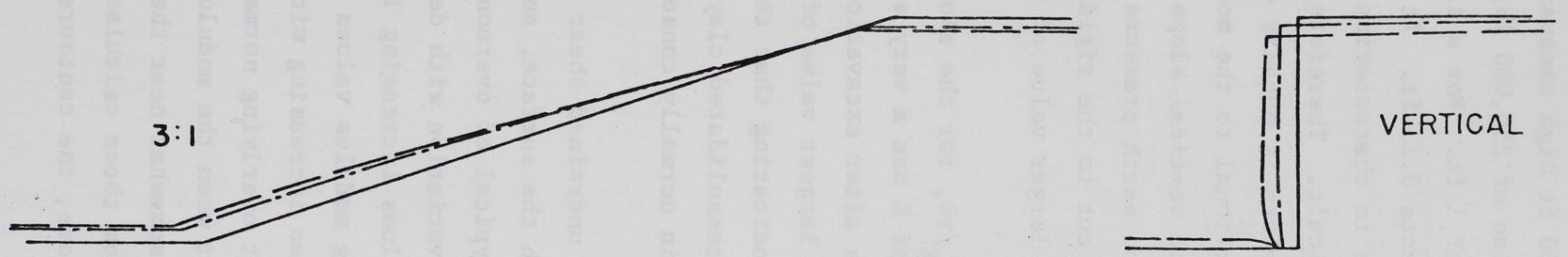

$\omega$

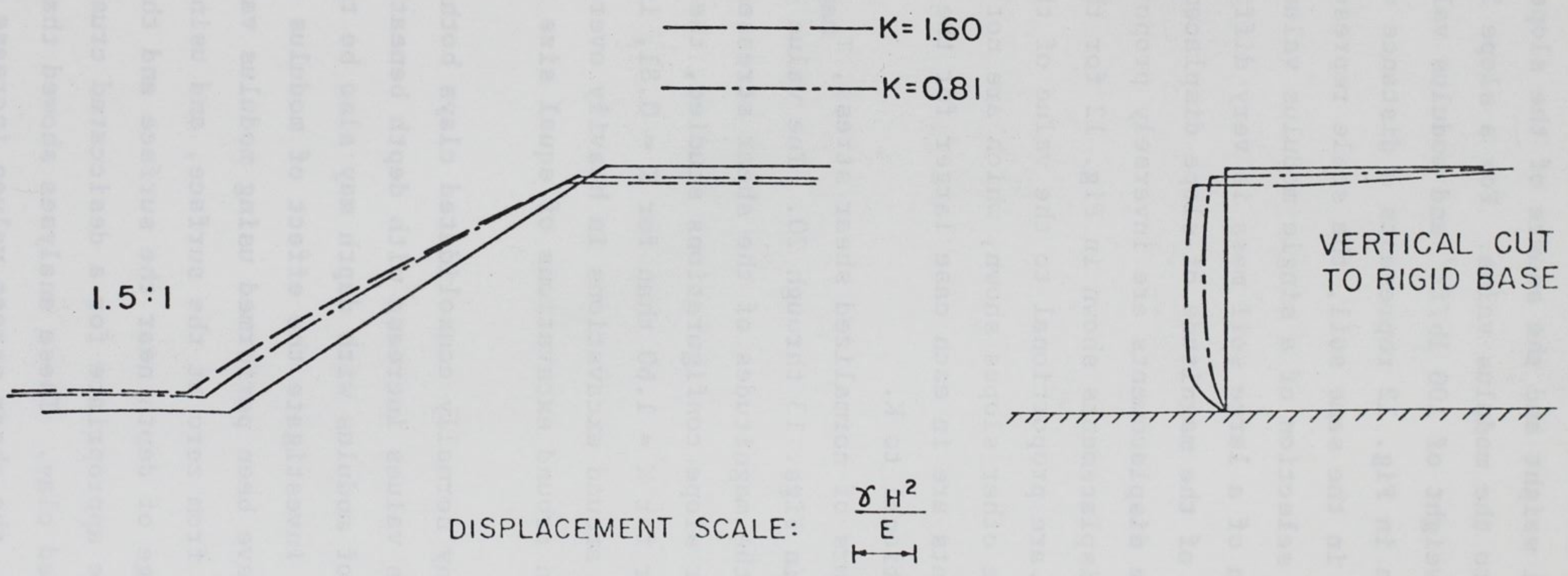

FIG. 12. SLOPE DISPLACFMENTS. 
indicating that the magnitudes of the slope displacements are proportional to the unit weight and the square of the slope height, and inversely proportional to the modulus value. For a slope $50 \mathrm{ft}$ high excavated in soil with unit weight of $100 \mathrm{lb} / \mathrm{ft}^{3}$ and modulus value of $250,000 \mathrm{lb} / \mathrm{ft}^{2}$, the scale shown in Fig. 12 represents a distance of $1 \mathrm{ft}$. For a slope $25 \mathrm{ft}$ high in the same soil, the scale represents $0.25 \mathrm{ft}$. It may be noted that selection of a single modulus value to characterize the deformation of a large soil mass is very difficult. Therefore accurate prediction of the magnitude of slope displacements is equally difficult, because the displacements are inversely proportional to the modulus value.

The displacements shown in Fig. 12 for the vertical slope cut to a rigid base are proportional to the value of the earth pressure coefficient K. For the other slopes shown, which are not cut to the rigid base, the displacements are in each case larger for the larger value of $\mathrm{K}$, but are not proportional to $\mathrm{K}$.

Contours of normalized shear stress, $\tau_{\max } / \gamma \mathrm{H}$, for the slopes analyzed are shown in Figs. 13 through 20. The value of $\mathrm{K}$ has a very significant effect on the magnitudes of the shear stresses after excavation. For each of the four slope configurations studied, the largest value of $\tau_{\max } / \gamma \mathrm{H}$ is much higher for $K=1.60$ than for $K=0.81$, indicating that the stress conditions around excavations in heavily overconsolidated clays are more severe than around excavations of equal size in normally consolidated clays.

In many normally consolidated clays both undrained shear strength and modulus values increase with depth beneath the surface, and some variation of modulus with depth may also be typical of overconsolidated clays. To investigate the effect of modulus variation with depth, analyses have been performed using modulus values increasing linearly with depth from zero at the surface, and using modulus values constant over a range of depth near the surface and then increasing with depth as would be appropriate for a desiccated crust overlying normally consolidated clay. These analyses showed that when the modulus increases with depth, the shear stress values increase somewhat near the base of the layer, but are not very much different from those calculated assuming uniform modulus throughout the layer. Therefore, the contours shown in 


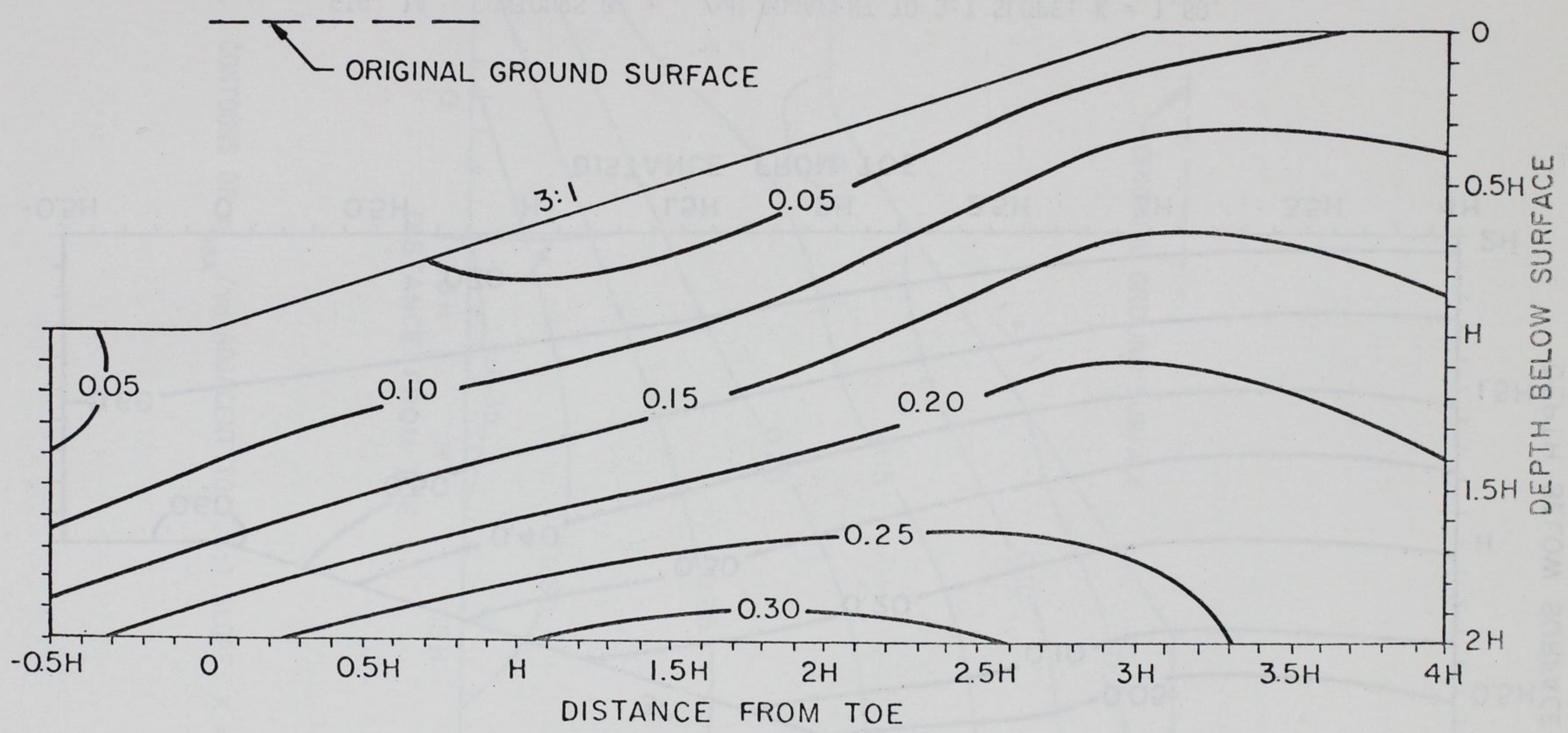

FIG. 13. CONTOURS OF $\tau_{\max } / \gamma H$ ADJACENT TO $3: 1$ SLOPE, $K=0.81$. 


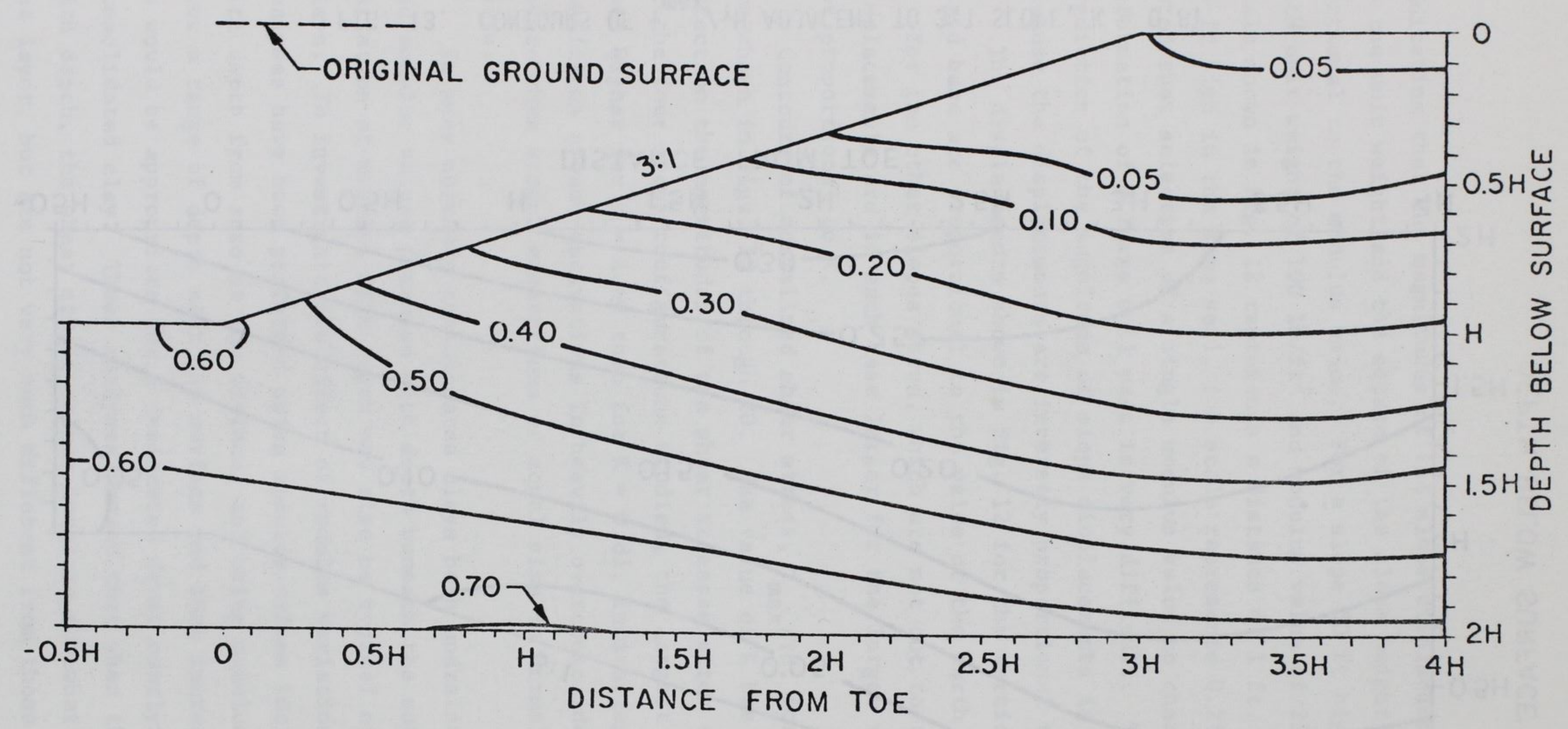

FIG. 14. CONTOURS OF $\tau_{\max } / \gamma H$ ADJACENT TO $3: 1$ SLOPE; $K=1.60$. 


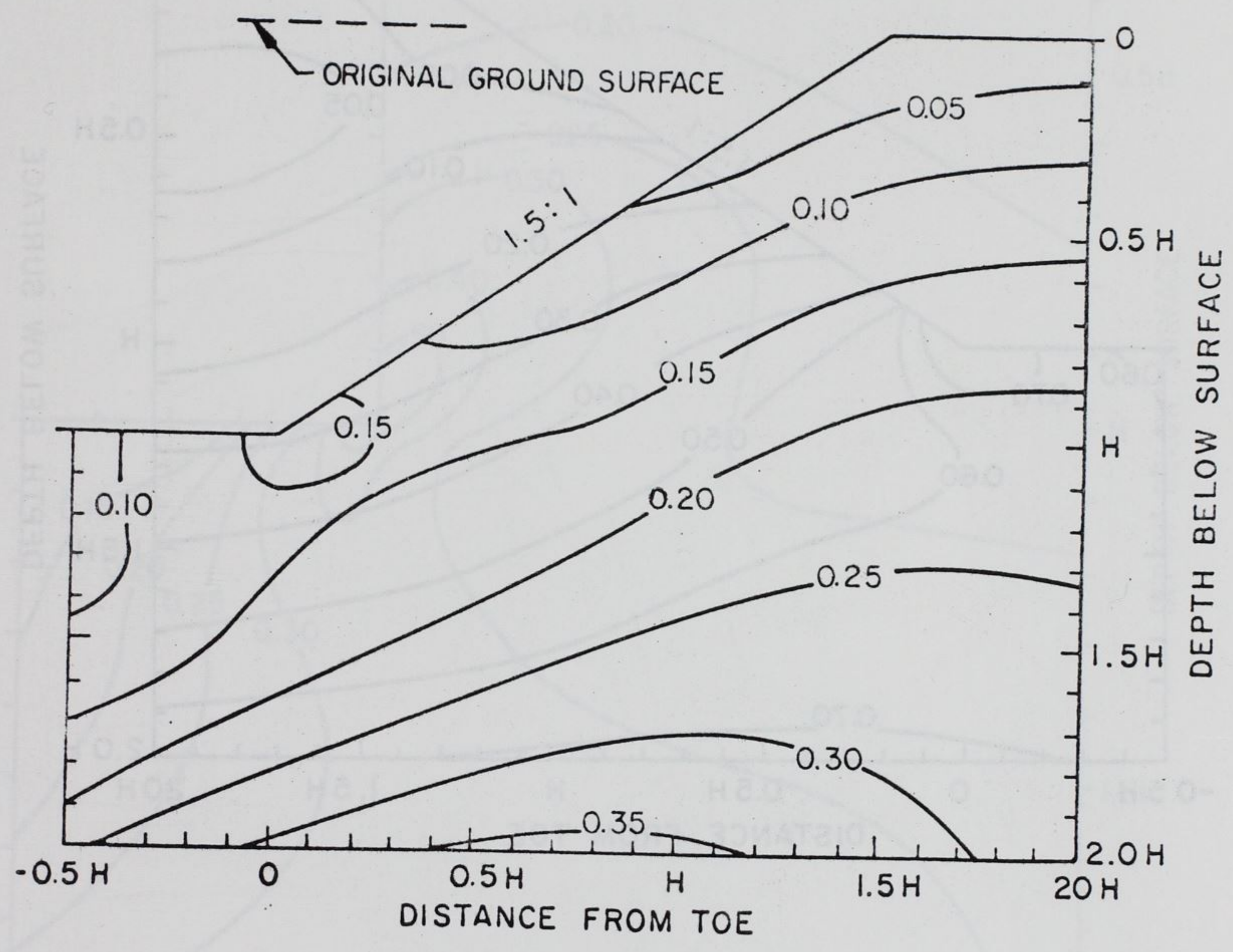

FIG. 15. CONTOURS OF $\tau_{\max } / \gamma H$ ADJACENT TO $1.5: 1$ SLOPE; $K=0.81$. 


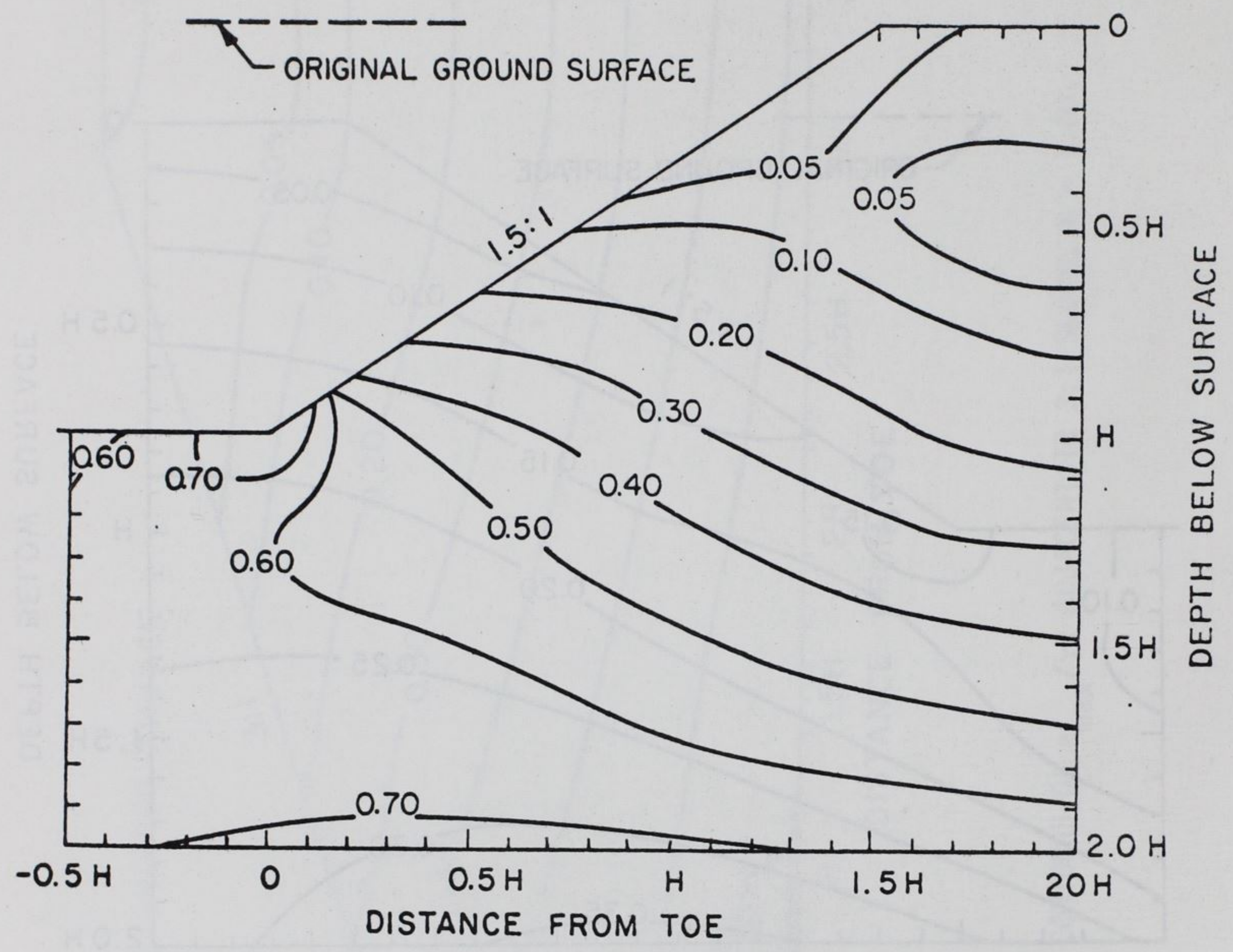

FIG. 16. CONTOURS OF $\tau_{\max } / \gamma H$ ADJACENI TO $1.5: 1$ SLOPE; $K=1.60$. 


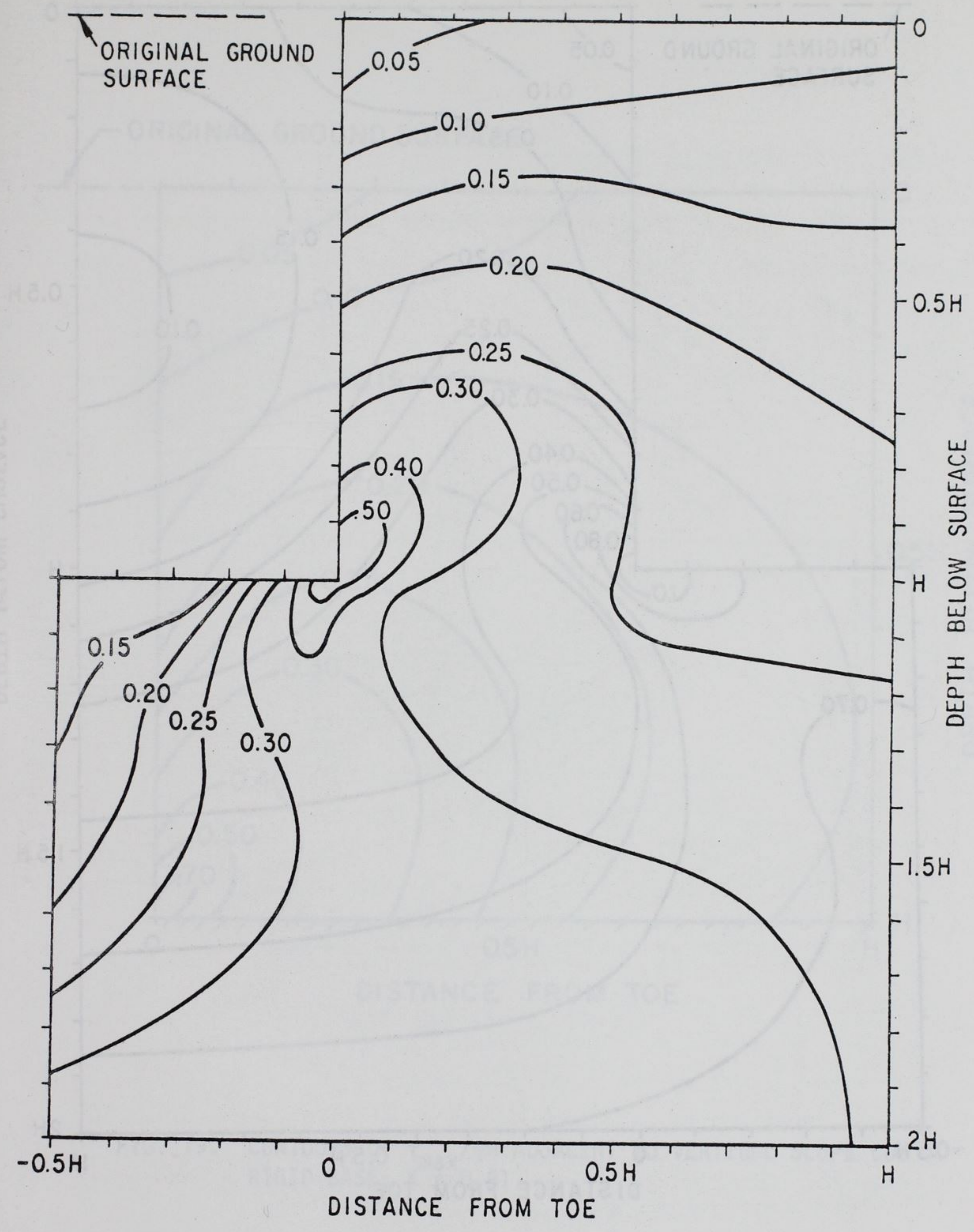

FIG. 17. CONTOURS OF $\tau_{\max } / \gamma H$ ADJACENT TO VERTICAL SLOPE; $K=0.81$. 


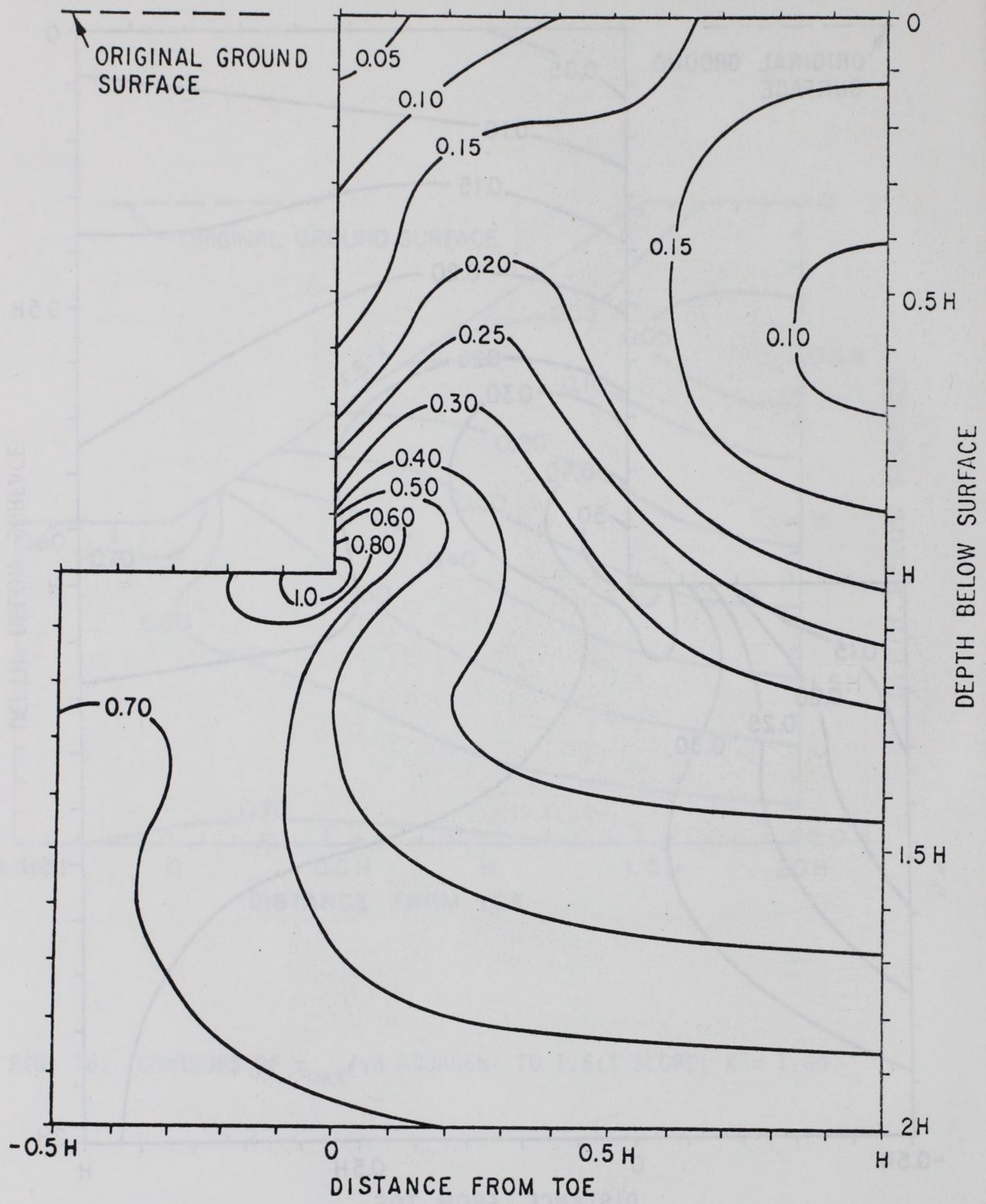

FIG. 18. CONTOURS OF $\tau_{\max } / \gamma H$ ADJACENT TO VERTICAL SLOPE: $K=1.60$. 


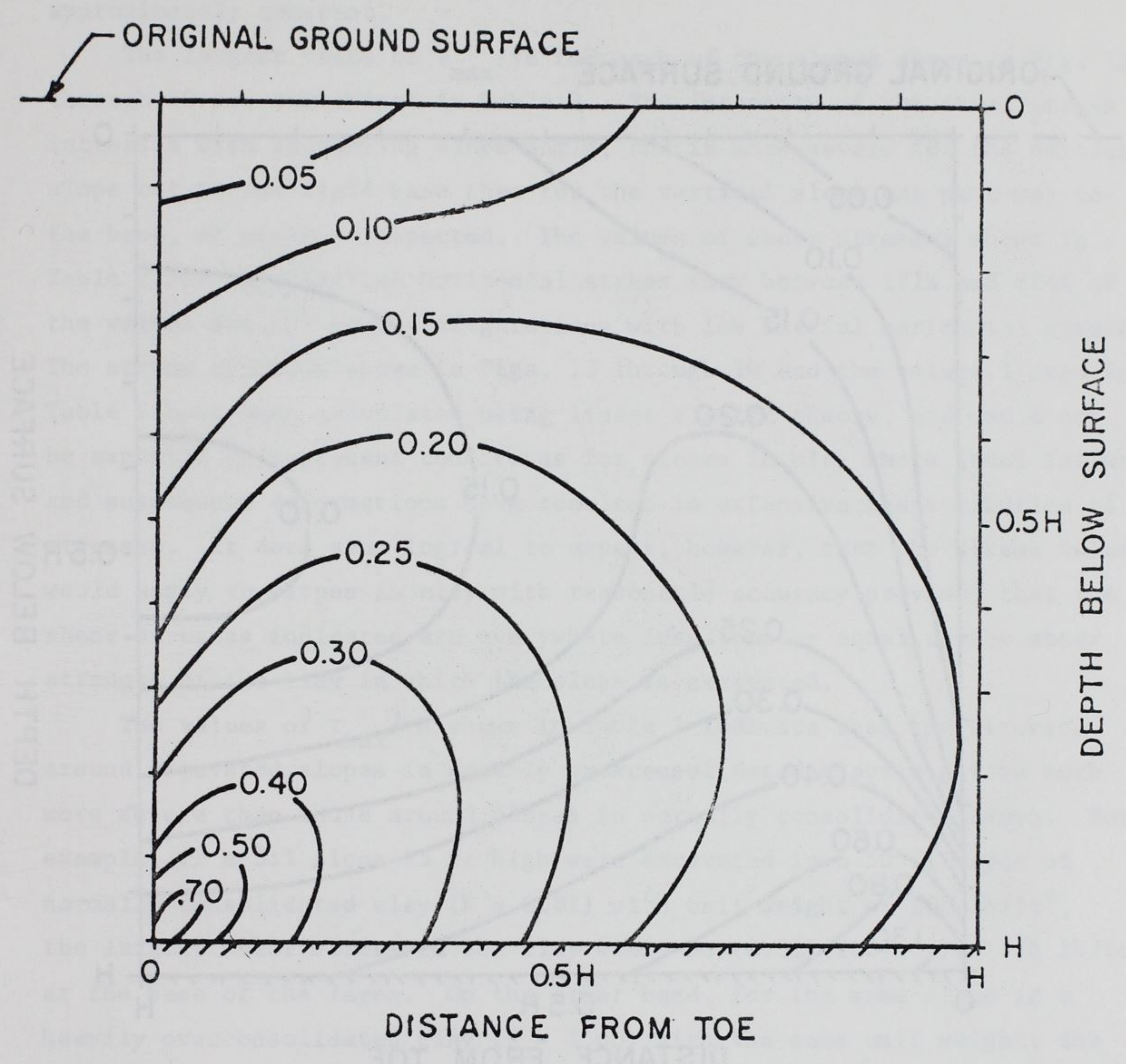

FIG. 19. CONTOURS OF $\tau_{\max } / \gamma H$ ADJACENT TO VERTICAL SLOPE CUT TO RIGID BASE; $K \stackrel{\max }{=} 0.81$. 


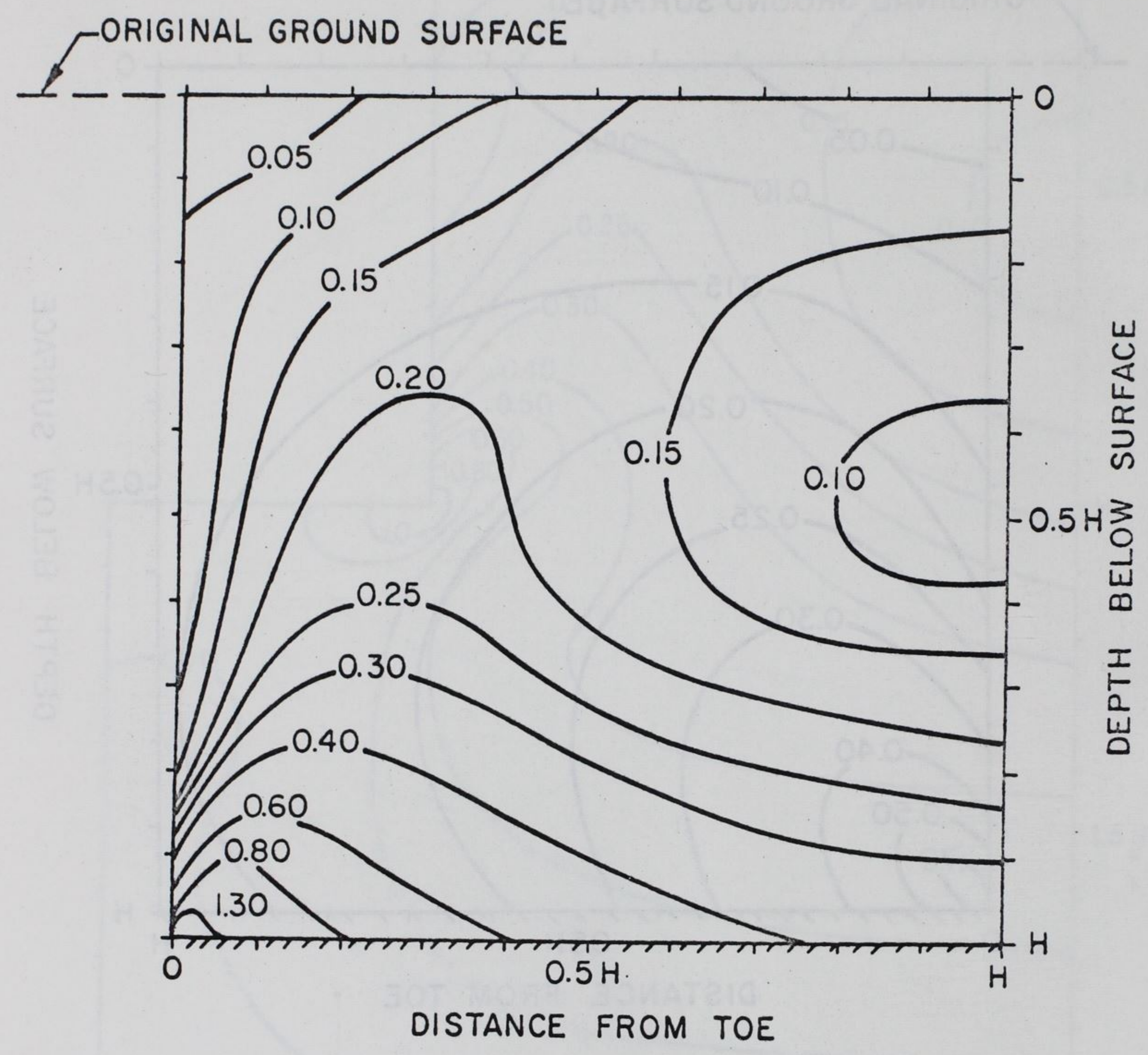

FIG. 20. CONTOURS OF $\tau_{\max } / \gamma H$ ADJACENT TU VERTICAL SLOPE CUT TO RIGID BASE; $K=1.60$. 
Figs. 13 through 20 may be considered applicable to cases where the modulus increases with depth, as well as to cases where the modulus is approximately constant.

The largest value of $\tau_{\max } / \gamma \mathrm{H}$ for each of the slopes shown in Fig. 13 through 20 are summarized in Table 2. The intensity of the shear stress increases with increasing slope angle, and is more severe for the vertical slope cut to the rigid base than for the vertical slope cut part-way to the base, as would be expected. The values of shear stresses shown in Table 2 for high initial horizontal stress vary between $171 \%$ and $224 \%$ of the values for the same configurations with low initial horizontal stress. The stress contours shown in Figs. 13 through 20 and the values listed in Table 2 have been calculated using linear elastic theory, and would not be expected to represent conditions for slopes in clay where local failure and subsequent deformations have resulted in extensive redistribution of stresses. It does seem logical to expect, however, that the stress values would apply to slopes in clay with reasonable accuracy provided that the shear stresses indicated are everywhere less than or equal to the shear strength of the clay in which the slope is excavated.

The values of $\tau_{\max } / \gamma \mathrm{H}$ shown in Table 2 indicate that the stresses around excavated slopes in heavily overconsolidated clays might be much more severe than those around slopes in normally consolidated clays. For example, if a 3:1 slope $25 \mathrm{ft}$ high were excavated in a $50 \mathrm{ft}$ layer of normally consolidated clay $(K=0.81)$ with unit weight of $1001 \mathrm{~b} / \mathrm{ft}^{3}$, the largest shear stress in the clay would be $(0.31)(100)(25)=7751 \mathrm{~b} / \mathrm{ft}^{2}$, at the base of the layer. On the other hand, for the same slope in a heavily overconsolidated clay $(K=1.60)$ with the same unit weight, the largest shear stress would be $(0.70)(100)(25)=1750 \mathrm{lb} / \mathrm{ft}^{2}$, also at the base of the layer. Thus the maximum shear stress in the overconsolidated clay would be more than twice as great as that in the normally consolidated clay, as a result of the higher values of initial horizontal stress.

Values of stability coefficient, $\mathrm{S}_{\mathrm{u}} / \gamma \mathrm{H}$, in which $\mathrm{S}_{\mathrm{u}}$ is the undrained strength, have been calculated for the slopes analyzed using two different methods, and are listed in Table 3. Those listed in the column headed "largest shear stress" are the values of $\tau_{\max } / \gamma \mathrm{H}$ shown in $\mathrm{Table} 2$, and represent the strength required to prevent failure at all except a single 
TABLE 2. VALUES OF $\tau_{\max } / \gamma \mathrm{H}$ FOR EXCAVATED SLOPES

\begin{tabular}{|c|c|c|c|}
\hline \multirow{2}{*}{ Slope } & $\mathrm{K}$ & $\begin{array}{c}\text { Largest Value } \\
\text { of } \tau_{\max } / \gamma^{\mathrm{H}}\end{array}$ & Location \\
\hline \multirow{2}{*}{$3: 1$} & 0.81 & 0.31 & Base \\
\cline { 2 - 4 } & 1.60 & 0.70 & Base \\
\hline \multirow{2}{*}{$1.5: 1$} & 0.81 & 0.36 & Base \\
\cline { 2 - 4 } & 1.60 & 0.78 & Toe \\
\hline \multirow{2}{*}{ Vertical } & 0.81 & 0.57 & Toe \\
\cline { 2 - 4 } & 1.60 & 1.01 & Toe \\
\hline \multirow{2}{*}{$\begin{array}{l}\text { Vertical Cut } \\
\text { to Rigid Base }\end{array}$} & 0.81 & 0.77 & Toe \\
\cline { 2 - 4 } & 1.60 & 1.32 & Toe \\
\hline
\end{tabular}


TABLE 3. VALUES OF $\mathrm{S}_{\mathrm{u}} / \gamma \mathrm{H}$ FOR EXCAVATED SLOPES

\begin{tabular}{|c|c|c|c|c|}
\hline \multirow{2}{*}{ Slope } & \multirow[b]{2}{*}{ K } & \multicolumn{2}{|c|}{$\mathrm{s}_{\mathrm{u}} / \gamma \mathrm{H}$} & \multirow[b]{2}{*}{ Ratio } \\
\hline & & $\begin{array}{c}\text { Largest } \\
\text { Shear Stress }\end{array}$ & $\begin{array}{c}\text { Average } \\
\text { Shear Stress }\end{array}$ & \\
\hline \multirow{2}{*}{$3: 1$} & 0.81 & 0.31 & 0.16 & 1.94 \\
\hline & 1.60 & 0.70 & 0.16 & 4.37 \\
\hline \multirow{2}{*}{$1.5: 1$} & 0.81 & 0.36 & 0.175 & 2.06 \\
\hline & 1.60 & 0.78 & 0.175 & 4.45 \\
\hline \multirow{2}{*}{ Vertical } & 0.81 & 0.57 & 0.26 & 2.19 \\
\hline & 1.60 & 1.01 & 0.26 & 3.89 \\
\hline \multirow{2}{*}{$\begin{array}{l}\text { Vertical Cut } \\
\text { to Rigid Base }\end{array}$} & 0.81 & 0.77 & 0.26 & 2.96 \\
\hline & 1.60 & 1.32 & 0.26 & 5.07 \\
\hline
\end{tabular}


location within the slopes. Those listed in the column headed "average shear stress" were determined from Taylor's (38) slope stability charts for $\phi=0$, and therefore represent the strength required for equilibrium along the most critical circular arc, assuming the soil has plastic stressstrain characteristics. The ratio of the values of $\mathrm{S}_{\mathrm{u}} / \gamma \mathrm{H}$ determined by the two methods are also shown in the table. The values of the ratio shown in Table 3 represent the factor of safety, calculated by the " $\phi_{\mathrm{u}}=0$ " method, for which failure would develop at one location within the clay layer. For the analyses representing excavations in normally consolidated clays the values of factor of safety corresponding to the onset of failure range from about 2.0 to 3.0 , and for the analyses representing heavily overconsolidated conditions, they range from about 4.4 to 5.1. Therefore it may be seen that the factor of safety corresponding to failure at a single location depends on the initial stress conditions, the slope inclination, and the rigidity of the material at the base of the excavation.

For a completely brittle soil or rock, which lost all shear resistance after failure, it would be appropriate to design against failure at any location within the slope. This procedure would require factors of safety (by the equilibrium method of analysis) as high as 5.1 for the most critical case shown in Table 3. For soils which do not suffer complete loss of shear resistance after failure however, it is not necessary to prevent failure at all locations to insure overall stability of the slope; smaller factors of safety have been successfully used for many slopes. Although it may not be necessary to prevent failure completely, it may be appropriate to recognize the influences of initial stress conditions and stress-strain characteristics by employing higher factors of safety in cases where these factors exert the most significant influence--for slopes in heavily overconsolidated stiff-fissured clays.

\section{CONCLUSIONS}

Many well-documented case histories show that the instability of slopes in stiff-fissured clays and shales often cannot be explained in terms of peak strength values determined by laboratory tests and equilibrium methods of stability analysis. These case histories include 
failures of embankment foundations, excavations, and natural slopes, and encompass failures during construction as well as many years later.

Studies of the properties of heavily overconsolidated clays and shales have disclosed a number of factors which may contribute to the difference between peak laboratory strength values and the shear resistance which can be mobilized in-situ. The initial stresses in overconsolidated clays and shales may also adversely influence the postconstruction stresses and the stability of slopes. Field and laboratory studies of the stresses in heavily overconsolidated clays and shales show that they are characterized by large horizontal stresses, and thus have a greater tendency for lateral rebound than normally consolidated clays.

Analyses of the stress conditions around excavated slopes described herein indicate that the initial horizontal earth pressures have a considerable influence on the magnitudes of shear stresses following construction. Shear stresses around excavated slopes are much larger for conditions representing a heavily overconsolidated clay (high initial horizontal stresses) than for conditions representing a normally consolidated clay (low initial horizontal stresses). The results indicate that shear stresses large enough to cause failure may develop at some points within the slopes, even though the factor of safety according to the usual $\phi_{u}=0$ method is considerably greater than unity. The higher the horizontal stresses before construction, the higher the factor of safety corresponding to development of local failure around the slope. Therefore it would be expected, as Bjerrum has suggested, that the existence of high horizontal stresses in heavily overconsolidated clays and shales increases the probability of progressive failure in these materials. 
1. Beene, R. R. W. (1967) "Waco Dam Slide," Journal of the Soil Mechanics and Foundations Division, ASCE, Vo1. 93, No. SM4, pp. 35-44.

2. Bishop, A. W. (1948) "Some Factors Involved in the Design of a Large Earth Dam in the Thames Valley," Proceedings of the 2nd International Conference on Soil Mechanics and Foundation Engineering, Vo1. 2, p. 13.

3. Bishop, A. W. (1955) "The Use of the Slip Circle in the Stability Analysis of Slopes," Geotechnique, Vol. 5, pp. 7-17.

4. Bishop, A. W. and Henkel, D. J. (1957), "The Measurement of Soil Properties in the Triaxial Test," London, Arnold.

5. Bishop, A. W. and Bjerrum, L. (1960) "The Relevance of the Triaxial Test to the Solution of Stability Problems," Proceedings of the ASCE Research Conference on the Shear Strength of Cohesive Soils, Boulder, pp. 437-501.

6. Bishop, A. W. (1966) "The Strength of Soils as Engineering Materials," Geotechnique, Vol. 16, No. 2, pp. 91-128.

7. Bjerrum, L. (1967) "Progressive Failure in Slopes of Overconsolidated Plastic Clay and Clay Shales," Journal of the Soil Mechanics and Foundations Division, ASCE, Vol. 93, No. SM5, pp. 1-49.

8. Brooker, E. W. and Ireland, H. O. (1965), "Earth Pressures at Rest Related to Stress History," Canadian Geotechnique Journal, Vo1. 2, No. 1, pp. 1-15.

9. Brooker, E. W. (1967) "Strain Energy and Behavior of Overconsolidated Soils," Canadian Geotechnical Journal, Vo1. 4, No. 3, pp. 326-333.

10. Brown, C. B. and King, I. P. (1966) "Automatic Embankment Analysis: Equilibrium and Instability Conditions," Geotechnique, Vo1. 16, No. 3, pp. 209-219.

11. Casagrande, A. and Wilson, S. D. (1952) "Effect of Rate of Loading on Strength of Clays and Shales at Constant Water Content," Geotechnique, Vol. 2, pp. 251-263.

12. Clough, R. W. (1960) "The Finite Element Method in Plane Stress Analysis," Proceedings of the 2nd ASCE Conference on Electronic Computation, Pittsburgh, $\mathrm{Pa}$.

13. Clough, R. W. (1965) "The Finite Element Method in Structural Mechanics," Chapter 7 of Stress Analysis, edited by Zienkiewicz and Hollister, John Wiley and Sons, London. 
14. Clough, R. W. and Woodward, R. J., III (1967) "Analysis of Embankment Stresses and Deformations," Journal of the Soil Mechanics and Foundations Division, ASCE, Vol. 93, No. SM4, pp. 529-549.

15. Duncan, J. M. and Seed, H. B. (1966) "Anisotropy and Stress Reorientation Effects in Clays," Journal of the Soil Mechanics and Foundations Division, ASCE, Vol. 92, No. SM5, pp. 21-50.

16. Finn, W. D. L. (1967) "Static and Dynamic Behavior of an Earth Dam," Canadian Geotechnical Journal, Vol. 4, No. 1.

17. Finn, W. D. L. (1966) "Static and Seismic Analysis of Slopes," Journal of the International Society of Rock Mechanics--Rock Mechanics and Engineering Geology.

18. Finn, W. D. L. (1966) "Static and Dynamic Stresses in Slopes," Proceedings of the 1st International Congress on Rock Mechanics.

19. Hansen, J. B. (1962) "Relationships between Stability Analyses with Total and with Effective Stresses," Sols-Soils, Vol. 3, pp. 28-39.

20. Henkel, D. J. and Skempton, A. W. (1955) "A Landslide at Jackfield, Shropshire, in a Heavily Overconsolidated Clay," Geotechnique, Vol. 5, No. 2, pp. 131-142.

21. Henke1, D. J. (1957) "Investigation of Two Long-Term Failures in London Clay Slopes at Wood Green and Northolt," Proceedings of the 4 th International Conference on Soil Mechanics and Foundation Engineering, Vo1. 2, pp. 315-320.

22. Herrmann, H. G. and Wolfskill, L. A. (1966) "Residual Shear Strength of Weak Shales," Report 5 of Waterways Experiment Station Technical Report 3-699," Engineering Properties of Nuclear Craters."

23. Hirschfeld, R. C., Whitman, R. V., and Wolfskill, L. A. (1965) "Review and Analysis of Available Information on Slopes Excavated in Weak Shales," Report 3 of Waterways Experiment Station Technical Report 3-699," Engineering Properties of Nuclear Craters."

24. Kenney, T. C. (1963) "Stability of Cuts in Soft Soils," Journal of the Soil Mechanics and Foundations Division, ASCE, Vo1. 89, No. SM5, pp. 17-37.

25. Kjellman, W. (1936) "Report on an Apparatus for Consumate Investigation of the Mechanical Properties of Soils," Proceedings of the 1st International Conference on Soil Mechanics and Foundation Engineering, Vo1. 2, pp. 16-20.

26. Langer, K. (1963) Discussion of Field Observations Reported by K. Terzaghi, Proceedings 1st International Conference on Soil Mechanics and Foundation Engineering, Vol. 3, pp. 152-155.

27. Peterson, R. (1955) Closure to discussion of Proc. Paper 476 "Studies of Bearpaw Shale at a Damsite in Saskatchewan," by R. Peterson; Proceedings Paper No. 759 , pp. 1-2.

28. Peterson, R., Iverson, N. L. and Rivard, P. J. (1957) "Study of Severa1 Dam Failures on Clay Foundations," Proceedings of the 4th International Conference on Soil Mechanics and Foundation Engineering, Vo1. 2, p. 348. 
29. Peterson, R., Jaspar, J. L., Rivard, P. J. and Iverson, N. L. (1960) "Limitations of Laboratory Shear Strength in Evaluating Stability of Highly Plastic Clays," Proceedings of the ASCE Research Conference on the Shear Strength of Cohesive Soils, Boulder, pp. 765-791.

30. Sevaldson, R. A. (1956) "The Slide in Lodalen, October 6th, 1954," Geotechnique, Vol. 6, No. 4, pp. 167-182.

31. Sherif, M. A. and Chen, J. T. (1967) "Application of the FiniteElement Method to Stress Distribution in Soil Media," Quarterly Journal of the University of Washington, College of Engineering, October, 1967.

32. Skempton, A. W. (1945) "A Slip in the West Bank of the Eau Brink Cut," Journal of the Institution of Civil Engineers, Vo1. 24, No. 7, pp. 267-287.

33. Skempton, A. W. (1948) "The $\phi=0$ Analysis of Stability and Its Theoretical Basis," Proceedings of the 2nd International Conference on Soil Mechanics and Foundation Engineering, Vol. 1, pp. 145-150.

34. Skempton, A. W. (1961) "Horizontal Stresses in an Overconsolidated Eocene Clay," Proceedings of the 5th International Conference on Soil Mechanics and Foundation Engineering, Vo1. 1, pp. 351-357.

35. Skempton, A. W. and Brown, J. D. (1961) "A Landslide in Boulder Clay at Selset, Yorkshire," Geotechnique, Vol. 11, No. 4, pp. 280293.

36. Skempton, A. W. (1964) "Long-term Stability of Clay Slopes," Geotechnique, Vol. 14, No. 2, pp. 77-102.

37. Skempton, A. W. and LaRochelle, P. (1965), "The Bradwell Slip: A Shortterm Failure in London Clay," Geotechnique, Vol. 15, No. 3, pp. 221242 .

38. Taylor, D. W. (1948) Fundamentals of Soil Mechanics, John Wiley \& Sons, New York.

39. Terzaghi, K. (1936) "Stability of Slopes in Natural Clay," Proceedings of the 1st International Conference on Soil Mechanics and Foundation Engineering, Vol. 1, pp. 161-165.

40. Van Auken, F. M., (1963) "Shear Strength of Clay-Shales Found in the Southwestern U.S.A." Proceedings of the 2nd PanAmerican Conference on Soil Mechanics and Foundation Engineering, Vol. 1, pp. 255-287.

41. Ward, W. H. (1957) Discussion, Proceedings of the 4th International Conference on Soil Mechanics and Foundation Engineering, Vo1. 3, pp. 123-124.

42. Ward, W. H., Samuels, S. G. and Butler, M. E. (1959) "Further Studies of the Properties of London Clay," Geotechnique, Vol. 9. No. 2, pp. 33-58. 
43. Whitman, R. V. and Bailey, W. A. (1967) "The Use of Computers for Slope Stability Analysis," Journal of the Soil Mechanics and Foundations Division, ASCE, Vo1. 93, No. SM4, pp. 475-498.

44. Wilson, E. L. (1963) "Finite Element Analysis of Two Dimensional Structures," Thesis presented to the University of California, Berkeley, in partial fulfillment of the requirements for the degree of Doctor of Philosophy. 


\section{DOCUMENT CONTROL DATA. R \& D}

(Security classification of thtle, body of abstrect and indexing annotation must be ontored ORIGINA TING Za. REPORT SECURITY CLASSIFICATION College of Engineering, Office of Research Services University of California, Berkeley, Calif.

REPORT TITLE

SLOPES IN STIFF-FISSURED CLAYS AIVD SHALES

4. OESCRIPTIVE NOTES (TYPe of report and inclusive dates)

Final report

5. AU THOR(S) (Firat name, middle initial, last name)

James M. Duncan

Peter Dunlop

\begin{tabular}{|c|c|c|}
\hline $\begin{array}{l}\text { 6. REPORT DATE } \\
\text { June } 1968 \\
\end{array}$ & $\begin{array}{l}\text { 7a. TOTAL NO. OF PAGES } \\
52\end{array}$ & $\begin{array}{c}\text { 7b. NO. OF REFS } \\
44 \\
\end{array}$ \\
\hline $\begin{array}{l}\text { 8a. CONTRACT OR GRANTNO. } \\
\text { DA-22-079-CIVENG-62-47 } \\
\text { b. PROJECT NO. }\end{array}$ & \multicolumn{2}{|c|}{ 9a. ORIGINATOR'S REPORT NUMBER(S) } \\
\hline d. & \multicolumn{2}{|c|}{$\begin{array}{l}\text { 9b. OTHER REPORT NO(S) (Any other number that may bo aseisned } \\
\text { this roport) } \\
\text { U. S. Army Engineer Waterways } \\
\text { Experiment Station Contract Report S-68-4 }\end{array}$} \\
\hline
\end{tabular}

This document has been approved for public release and sale; its distribution is unlimited.

\begin{tabular}{|l|l|}
\hline 11. SUPPLEMENTARY NOTES & $\begin{array}{l}\text { 12. SPONSORING MILITARY ACTIVITY } \\
\text { U. S. Army Engineer Waterways EXperiment } \\
\text { Station, Vicksburg, Miss. }\end{array}$
\end{tabular}

13. ABSTRACT

The objective of this investigation was to review existing information concerning slope failures in stiff, fissured clays and shales, and to study the influence of lateral stresses on the stress conditions around excavated slopes. These studies, which were performed using the finite element method of analysis, show that the initial horizontal pressures have a considerable influence on the magnitudes of shear stresses following construction. Shear stresses around excavated slopes are much larger for conditions representative of heavily overconsolidated clays (high initial horizontal stresses) than for conditions representative of normally consolidated clays (low initial horizontal stresses). Shear stresses large enough to cause failure at some points may develop even when the factor of safety calculated by the $\phi=0$ method of analysis is much larger than unity. The higher the horizontal stresses before excavation, the higher the factor of safety corresponding to the development of local failure. 
Unclassified

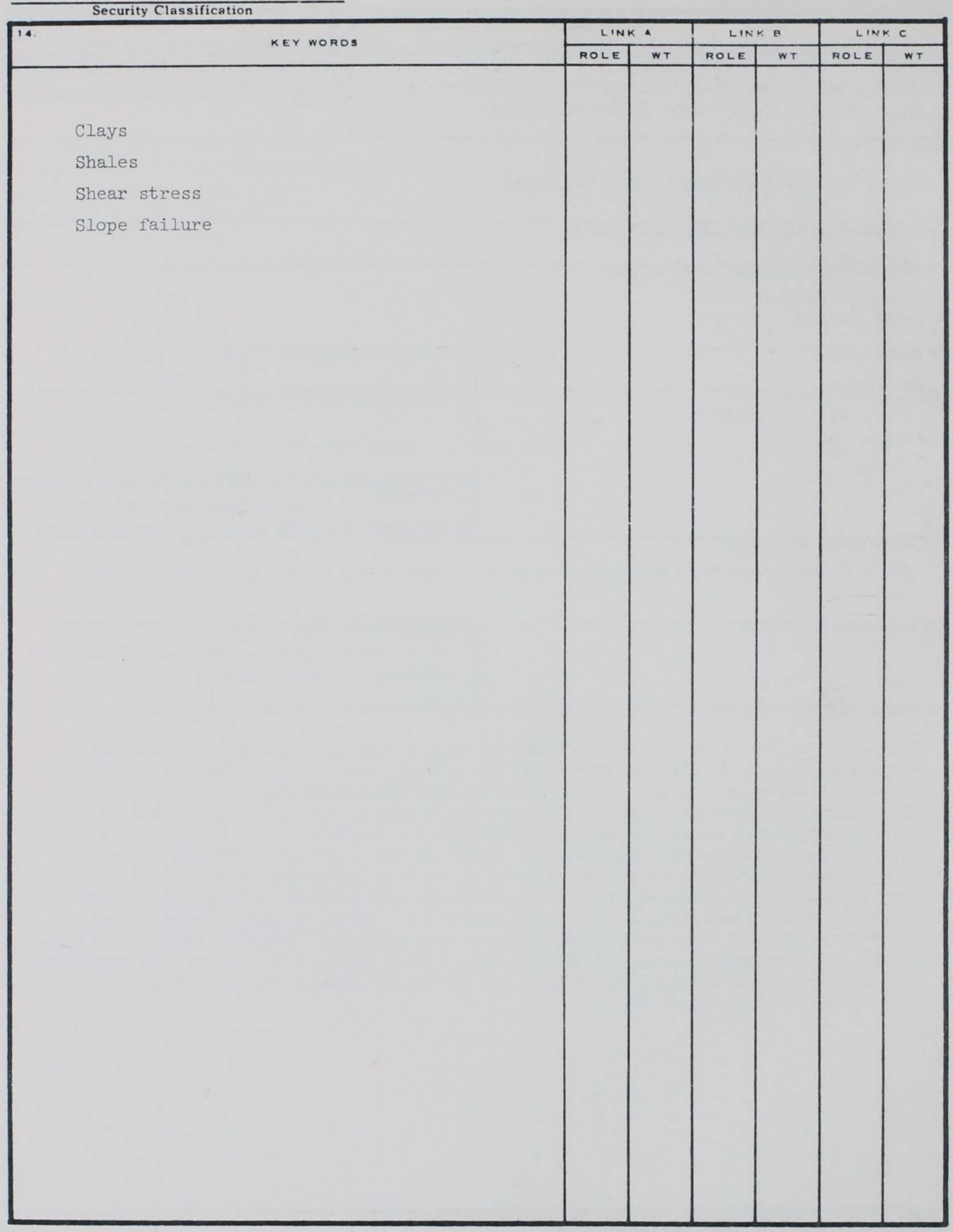

Unclassified

Security Classification 